\title{
Comprehensive study on the antioxidant capacity and phenolic profiles of black seed and other spices and herbs: effect of solvent and time of extraction
}

\author{
Małgorzata Muzolf-Panek ${ }^{1}$ (I) Kinga Stuper-Szablewska $^{2}$
}

Received: 27 February 2021 / Accepted: 14 June 2021 / Published online: 26 June 2021

(c) The Author(s) 2021

\begin{abstract}
The effects of solvent and time of extraction on the antioxidant properties and phenolic profiles of 13 herbs and spices used for food seasoning and preservation were investigated. The profiles of phenolics in plant material were analysed by UPLC, and the chemometric approach was used for the deeper evaluation of relationships between phenolic compounds and the antioxidant properties of the samples. The best extraction conditions enabling to obtain the highest total phenolics and the antioxidant activity were: long time extraction $(24 \mathrm{~h})$ with $50 \%$ aqueous ethanol. The most potent antioxidant was clove with the ABTS - 2495.85 $\mu \mathrm{mol} / \mathrm{g}$, DPPH $-1443.35 \mu \mathrm{mol} / \mathrm{g}$ and FRAP $-1310.91 \mu \mathrm{mol} / \mathrm{g}$, which resulted from the high total phenolic content (TPC $-167.22 \mathrm{mg} \mathrm{GAE} / \mathrm{g}$ ) and total flavonoid content (TFC—26.22 $\mathrm{mg} \mathrm{QE} / \mathrm{g}$ ). Wide variations in the antioxidant activity (ABTS: $7.31-2495.85 \mu \mathrm{mol} / \mathrm{g})$ and TPC $(0.87-167.22 \mathrm{mg} \mathrm{GAE} / \mathrm{g})$ were observed with black seed extract showing one of the lowest values of the parameters studied. High linear correlation (above 0.95) calculated for the parameters showed significant contribution of phenolics to the antioxidant activity of spices. UPLC analysis together with PCA (principal component analysis) confirmed this relation and ABTS, FRAP, DPPH, TFC, TPC, total phenolic acids, protocatechuic acid, $t$-cinnamic acid, $p$-hydroxybenzoic acid determined sample distribution along PC1 (principal component 1), whereas total flavonoids determined by UPLC, kaempferol, catechin and luteolin along PC2. All samples were discriminated with $100 \%$ classification's propriety according to GDA (general discrimination analysis) which proved huge diversity among phenolic profiles and the antioxidant properties of tested samples.
\end{abstract}

Keywords Antioxidant activity $\cdot$ Extraction conditions $\cdot$ Herbs $\cdot$ Phenolic profile $\cdot$ Spices $\cdot$ UPLC

\section{Introduction}

Herbs and spices have been used for ages not only to improve flavour of food but also to preserve food from spoilage during storage, to cure or reduce the risk of human diseases. Nowadays, there are an increasing amount of studies

Małgorzata Muzolf-Panek

malgorzata.muzolf-panek@up.poznan.pl

Kinga Stuper-Szablewska

kinga.stuper@up.poznan.pl

1 Department of Food Quality and Safety Management, Faculty of Food Science and Nutrition, Poznań University of Life Sciences, Wojska Polskiego 31, 60-624 Poznań, Poland

2 Department of Chemistry, Faculty of Wood Technology, Poznań University of Life Sciences, Wojska Polskiego 75, 60-625 Poznań, Poland reported the beneficial effects of spices and herbs on food quality. They are used in food (meat, bread, dairy products) directly in their native forms (whole or ground materials) or, more often, as extracts. Spices and herbs have been also known as health-promoting agents and their extracts have been investigated as alternative treatments against various disorders such as gastric-intestinal and oral cavity disorders, cough and are widely used in pharmacy products [1]. Most of the beneficial properties of spices and herbs are ascribed to their high antioxidant capacity and one of the main group of compounds responsible for these properties are phenolics-secondary plant metabolites.

In general, a qualitative and quantitative characteristic of the plant extracts and therefore their effectiveness as antioxidant agents depends on the type of extraction and extraction conditions (temperature, particle size, pressure, solvent, sample-to solvent ratio etc.). Although various novel extraction techniques have been recently introduced and 
investigated such as: microwave-assisted extraction, ultrasound-assisted extraction, enzymatic-assisted extraction, pulsed electric field extraction, supercritical fluid extraction, natural deep eutectic solvent extraction, accelerated solvent extraction [2], the solvent extraction is still the most frequently used procedure to obtain extracts from plant materials. The pros of this process are as follows: ease of use, wide applicability and no need of usage the advanced equipment. However, from the environmental point of view the solvent extraction does not belong to the green chemistry methods since a great number of waste are produced with potentially dangerous residues depending on type of solvent used. The crucial step of the extraction process is to select appropriate solvent which determines the profile of bioactive compounds eluted. There is a huge diversity of compounds only within the group of phenolics which is the result of their various chemical structures from a single hydroxylated aromatic ring (phenolic acids) to highly complexed polymeric substances (tanins, and lignans) [3]. The high diversity of phenolics is also the straight effect of the multiple functional groups varying in type, number and position in the compound structure [3]. The various hydroxylation, methocylation, glycosylatioan and acylation patterns could occur in the phenolic structure. Thus, the physico-chemical properties of phenolics, including their solubility, could vary in a broad range. It was previously reported that the profile of phenolic compounds extracted from plant depends on the polarity of the eluate used for the extraction [1, 4]. Methanol and ethanol were the most commonly used solvents with relative polarity of 0.762 and 0.654 , respectively [4-6] and water (relative polarity $=1$ ) in various proportion has been often added to increase their polarity [4, 6-9]. Also solvents like acetone, chloroform, hexane, diethyl ether, butanol and their combination with other solvents have been used $[1,4,10]$. Although from the safety point of view ethanol and ethanol-water solvents could be introduced into food without the risk of product contamination with toxic solvent residues.

In the previous research on food quality a diverse methods of extraction have been applied to spices and herbs [9], thus it is difficult to compare the phenolic content and the antioxidant effectiveness of these plant extracts between various studies. Moreover, the antioxidant action of extracted compounds could be an effect of various mechanisms, including radical scavenging capacity (based on different radicals) or metal chelating properties (reducing abilities). And even when the method of the antioxidant activity measurement is the same, the exact procedure could vary significantly depending on the applied modifications.

The most commonly used methods for the measurements of the radical scavenging properties are ABTS and DPPH assays. Both assays are based on single electron transfer (SET) mechanisms (although the hydrogen atom donation could also occur) using stable free radicals whose reduction by the antioxidant could be easily monitored by the spectrophotometer at visible region [11-14]. Nevertheless, both radicals are not relevant to biological system (they are nonphysiological radicals) [15]. ABTS ${ }^{\bullet+}$ cation radicals are soluble in aqueous and organic solvents, hence both non-polar and polar samples can be assessed. These cation radicals can be used at different $\mathrm{pH}$ which is very useful when studying the effectiveness of various plant materials [15]. Unlike $\mathrm{DPPH}^{\bullet}$ radicals dissolve in organic solvents and are sensitive to acidic $\mathrm{pH}$ (the acidic $\mathrm{pH}$ causes the decolourization of $\mathrm{DPPH}^{\bullet}$ radical solution which makes the radical scavenging ability of the antioxidant unable to measure) [15]. Additionally, the results of DPPH assay could be underestimated when monitoring the properties of samples containing anthocyanins since the color interference could occur between these flavonoids and DPPH solution [15]. Metal chelating properties of the samples are often investigated by the FRAP (ferric reducing antioxidant power) assay in which the reduction of ferric iron $(\mathrm{Fe} 3+)$ to ferrous iron $(\mathrm{Fe} 2+)$ is monitored [16]. The assay is also based on SET mechanism and is $\mathrm{pH}$-dependent $[6,16]$.

Although the antioxidant activity and phenolic compound contents of herbs and spices have been widely investigated, a comprehensive study on their qualitative and quantitative characteristic in various extraction conditions using various methods of the antioxidant activity measurements is still lacking. Moreover, the information on the antioxidant activity of black seed is rather limited, as the spice is mainly studied as a source of fatty acids.

Thus, the main aim of this study was to investigate the effects of solvent and time of extraction on the antioxidant potential and phenolic content of 13 herbs and spices used for food seasoning and preservation. The profiles of phenolics in the most potent antioxidant active extracts were also analysed by UPLC, and the chemometric approach was used for the deeper assessment of relationships between phenolics and the antioxidant properties of the samples. The results of this study may be of interest to the food industry looking for naturally occurring antioxidants as alternatives to conventional and synthetic preservatives.

\section{Materials and methods}

\section{Chemicals}

2,2'-azinobis-(3-ethylbenzothiazoline-6-sulfonic acid) (ABTS), 2,2-diphenyl-1-picrylhydrazyl (DPPH), 2,4,6-tripyridyl-s-triazine (TPTZ), 6-hydroxy-2,5,7,8-tetramethylchroman-2-carboxylic acid (Trolox-water-soluble vitamin E analogue), Folin-Ciocalteu reagent (FCR) were purchased from Sigma-Aldrich (Steinheim, Germany). Water was purified using the Milli-Q system (Millipore, Bedford, MA, 
USA). All organic solvents of HPLC grade were purchased from Sigma-Aldrich (Steinheim, Germany). All other chemical reagents and solvents used in this study were analytical grade and obtained from POCh (Gliwice, Poland).

\section{Extract preparation}

Dried allspice, basil, bay leaf, black seed, cardamom, caraway, cloves, garlic, nutmeg, onion, oregano, thyme, rosemary were purchased from local distributor (Ciecierzyn, Polska). All dried herbs and spices were grounded just before extraction. Then, $15 \mathrm{~g}$ of plant material was extracted with $225 \mathrm{~mL}$ of different solvent, namely: water, $50 \%$ aqueous ethanol or pure ethanol in a closed container at ambient temperature. All samples were mixed on the magnetic stirrer (MS-H-Pro plus, Chemland, Poland) with electronic control for constant speed. One batch of samples had been extracted for half an hour $(0.5 \mathrm{~h})$. The second batch of extracts was obtained during $24 \mathrm{~h}$. After filtration through 3HW Filtrak filter paper (Filtrak, Niederschlag Bärenstein, Germany) the antioxidant activity and phenolic content of the extracts were analyzed. For UPLC analysis all extract were freeze-dried and stored at $-20{ }^{\circ} \mathrm{C}$ during one week.

\section{Antioxidant activity}

The antioxidant activities of spice extracts were determined by methods, which reflected the mechanisms of free radical scavenging ( $\mathrm{DPPH}^{\bullet}$ and $\mathrm{ABTS}^{\bullet+}$ ) and chelation of transition metal ions (ferric-reducing antioxidant power-FRAP method). A combination of these methods enabled to get more insight into the antioxidant potential of the tested extracts.

The DPPH ${ }^{\bullet}$ free radical scavenging activity was investigated using the method of Sánchez-Moreno et al. [17] with some modifications [18]. The $\mathrm{DPPH}^{\bullet}$ radical scavenging activity was expressed as Trolox equivalent (TE) in $\mu \mathrm{mol}$ of Trolox per $\mathrm{g}$ of dried herb or spice.

The radical scavenging activity of plant extracts was also measured by the TEAC (Trolox Equivalent Antioxidant Capacity) assay using ABTS $^{\bullet+}$ cation radicals $[12,19]$ generated as described previously [20]. The results were expressed as TEAC (Trolox Equivalent Antioxidant Capacity) values in $\mu \mathrm{mol}$ Trolox/g of dried herb or spice.

To assess the ability of the plant extracts to chelate metal ions, the FRAP (ferric reducing antioxidant power) assay was implemented [16]. The reduction of a ferric tripyridyltriazine complex $(\mathrm{Fe}+3$-TPTZ) to a ferrous complex $(\mathrm{Fe}+2-\mathrm{TPTZ})$ by the extract was monitored at $593 \mathrm{~nm}$. The results were expressed as $\mu$ mol Trolox equivalent (TE) per $\mathrm{g}$ of dried herb or spice [21].

\section{Phenolic content}

Total polyphenol content (TPC) was measured according to the method of Singleton and Rossi [22] using FCR as described previously [21]. Briefly, an aliquot of $20 \mu \mathrm{L}$ of the plant extract was mixed with $100 \mu \mathrm{L}$ of Folin-Ciocaulteu's reagent, mixed and allowed to stand in dark for $3 \mathrm{~min}$. Then, $300 \mu \mathrm{L}$ of sodium carbonate $(20 \% \mathrm{~m} / \mathrm{v})$ was added and the sample was filled up to $2 \mathrm{~mL}$ with deionized water, mixed and put in the dark for $2 \mathrm{~h}$ at ambient temperature. After incubation, the absorbance readings at $765 \mathrm{~nm}$ were done against the blank sample prepared as above but with the corresponding solvent addition instead of the plant extract. The results were expressed as mg of gallic acid equivalents (GAE) per $\mathrm{g}$ of dried herb or spice.

Total flavonoid content (TFC) was assessed by the aluminum chloride method as described previously [21]. An aliquot of $100 \mu \mathrm{L}$ of spice extract was mixed with $2 \%(\mathrm{~m} / \mathrm{v})$ aluminum chloride in methanol (ratio 1:10) and allowed to stand for $15 \mathrm{~min}$ in dark at ambient temperature. Then, the absorbance was read at $415 \mathrm{~nm}$. The results were read from the calibration curve for quercetin and expressed in $\mathrm{mg}$ of quercetin equivalent $(\mathrm{QE})$ per $1 \mathrm{~g}$ of dried herb or spice.

The qualitative and quantitative analyses of phenolic compounds in extract studied were performed by UPLC [20]. Freeze-dried extracts after first alkaline and then acid hydrolysis were evaporated to dryness under nitrogen stream and dissolved in $1 \mathrm{~mL}$ of methanol. An Aquity $\mathrm{H}$ class UPLC system equipped with a Waters Acquity PDA detector (Waters, USA) and an Acquity UPLC® BEH C18 column $(100 \mathrm{~mm} \times 2.1 \mathrm{~mm}$, particle size $1.7 \mu \mathrm{m})$ (Waters, Ireland) were used. An elution gradient of the mobile phase composed of: acetonitryl with $0.1 \%$ formic acid (A), and $1 \%$ aqueous formic acid mixture ( $\mathrm{pH}$ 2) (B). Concentrations of flavonoids and phenolic acids were determined using internal standards at wavelengths of $320 \mathrm{~nm}$ and $280 \mathrm{~nm}$, respectively. Compounds were also identified based on external standard method. Detection level was $1 \mathrm{mg} / \mathrm{kg}$ freeze-dried extract (DW).

\section{Statistical analysis}

The statistical tests were performed using Statistica 13.0 software (Statsoft, Oklahoma, USA). The results were statistically significant at $p \leq 0.05$. ANOVA was used to estimate the significance of the variables (time, type of solvents, plant material) on the parameters studied. Duncan's test was used for post hoc analysis to show homogenous groups. Principal component analysis (PCA) was performed as a first step of data analysis to show the relations between parameters and to detect patterns in data as well as to lower the dimension of information for discrimination analysis. Finally, general discrimination analysis (GDA) was used to 
calculate classification rules for extract discrimination. Data for multivariate analysis was standardized. All analyses were run in triplicate.

\section{Results and discussion}

Three solvents, of various polarities, namely water, $50 \%$ ethanol in water and ethanol were used for the extraction of bioactive compounds from herbs and spices. Although, Rezaei et al. [23] reported that methanol appeared to be more effective solvent for polyphenol and flavonoid extraction than ethanol, its application in food industry is limited in regards to its safety for consumers. In our previous study [20,21] we reported that the addition of water-ethanol $(50 \%)$ plant extracts to pork and chicken meat decreased the lipid and protein oxidation. These properties could be in favor of the food producers as well as consumers since the quality of meat with plant extracts could be maintained for a longer time thus increasing the shelf-life of the product.

\section{Total phenolic content-effects of solvent, time and plant material}

Statistically significant effect of solvent was observed for TPC (Table 1, Fig. 1). Regardless of time of extraction and

Table 1 Total phenolic content (TPC) and total flavonoid content (TFC) of herbs and spices

\begin{tabular}{|c|c|c|c|c|c|c|}
\hline \multirow[t]{2}{*}{ Time of extraction } & \multicolumn{2}{|l|}{$50 \%$ ethanol } & \multicolumn{2}{|l|}{ Ethanol } & \multicolumn{2}{|l|}{ Water } \\
\hline & $0.5 \mathrm{~h}$ & $24 \mathrm{~h}$ & $0.5 \mathrm{~h}$ & $24 \mathrm{~h}$ & $0.5 \mathrm{~h}$ & $24 \mathrm{~h}$ \\
\hline Extracts & \multicolumn{6}{|l|}{ TPC mg GAE/g } \\
\hline Allspice & $28.96 \pm 3.34^{\mathrm{abB}}$ & $31.61 * \pm 0.81^{\mathrm{aB}}$ & $21.85 \pm 1.89^{\mathrm{bB}}$ & $25.6 \pm 2.31^{\mathrm{abB}}$ & $16.84 \pm 0.68^{\mathrm{cBC}}$ & $17.01 \pm 1.53^{\mathrm{cC}}$ \\
\hline Basil & $12.38 \pm 0.75^{\mathrm{bDEF}}$ & $14.81 \pm 0.35^{\mathrm{aD}}$ & $3.45 \pm 0.22^{\mathrm{eC}}$ & $6.1 \pm 0.16^{\mathrm{dE}}$ & $11.38 \pm 0.07^{\mathrm{cCD}}$ & $12.27 \pm 0.84^{\mathrm{bD}}$ \\
\hline Bay leaf & $23.18 \pm 0.35^{\mathrm{aBC}}$ & $22.56^{*} \pm 0.16^{\mathrm{aC}}$ & $11.47 \pm 0.79^{\mathrm{dBC}}$ & $20.65 \pm 1.21^{\mathrm{bC}}$ & $13.49 \pm 0.20^{\mathrm{cC}}$ & $11.9 \pm 0.36^{\mathrm{dD}}$ \\
\hline Black seed & $1.51 \pm 0.33^{\mathrm{bcG}}$ & $2.46^{*} \pm 0.60^{\mathrm{aEF}}$ & $0.95 \pm 0.06^{\mathrm{cC}}$ & $2.61 \pm 0.46^{\mathrm{aEF}}$ & $1.81 \pm 0.11^{\mathrm{bE}}$ & $1.8 \pm 0.06^{\mathrm{bF}}$ \\
\hline Cardamom & $1.31 \pm 0.10^{\mathrm{abG}}$ & $1.24 * \pm 0.01^{\mathrm{bF}}$ & $1.69 \pm 0.41^{\mathrm{aC}}$ & $1.39 \pm 0.10^{\mathrm{abF}}$ & $1.27 \pm 0.25^{\mathrm{bE}}$ & $1 \pm 0.07^{\mathrm{bF}}$ \\
\hline Carraway & $1.96 \pm 0.04^{\mathrm{bG}}$ & $2.39 * \pm 0.14^{\mathrm{aEF}}$ & $1.02 \pm 0.16^{\mathrm{cC}}$ & $1.17 \pm 0.06^{\mathrm{cF}}$ & $1.92 \pm 0.26^{\mathrm{bE}}$ & $2.43 \pm 0.46^{\mathrm{aF}}$ \\
\hline Cloves & $160.88 \pm 18.60^{\mathrm{aA}}$ & $167.22 * \pm 9.32^{\mathrm{aA}}$ & $130.9 \pm 26.88^{\mathrm{bA}}$ & $130.85 \pm 6.77^{\mathrm{bA}}$ & $85 \pm 13.13^{\mathrm{cA}}$ & $78.91 \pm 5.70^{\mathrm{cA}}$ \\
\hline Garlic & $3.97 \pm 0.13^{\mathrm{aFG}}$ & $3.6 \pm 0.05^{\mathrm{bEF}}$ & $0.89 \pm 0.14^{\mathrm{dC}}$ & $2.52 \pm 0.02^{\mathrm{cEF}}$ & $3.56 \pm 0.23^{\mathrm{bE}}$ & $3.53 \pm 0.19^{\mathrm{bF}}$ \\
\hline Nutmeg & $4.24 \pm 0.12^{\mathrm{aFG}}$ & $3.89^{*} \pm 0.14^{\mathrm{bEF}}$ & $3.97 \pm 0.36^{\mathrm{abC}}$ & $3.98 \pm 0.10^{\mathrm{abEF}}$ & $2.17 \pm 0.07^{\mathrm{cE}}$ & $2.64 \pm 0.10^{\mathrm{cF}}$ \\
\hline Onion & $5.89 \pm 0.19^{\mathrm{cEFG}}$ & $7.05 \pm 0.58^{\mathrm{abE}}$ & $2.74 \pm 0.65^{\mathrm{eC}}$ & $3.73 \pm 0.67^{\mathrm{dEF}}$ & $6.21 \pm 0.36^{\mathrm{bcDE}}$ & $7.23 \pm 0.30^{\mathrm{aE}}$ \\
\hline Oregano & $14.57 \pm 0.03^{\mathrm{bCDE}}$ & $20.69 \pm 0.99^{\mathrm{aC}}$ & $8 \pm 0.52^{\mathrm{dC}}$ & $10.9 \pm 0.73^{\mathrm{cD}}$ & $10.57 \pm 1.67^{\mathrm{cCD}}$ & $14.71 \pm 1.07^{\mathrm{bCD}}$ \\
\hline Rosemary & $1.6 \pm 0.07^{\mathrm{dG}}$ & $4.66 \pm 0.36^{\mathrm{bEF}}$ & $1.99 \pm 0.21^{\mathrm{dC}}$ & $5.69 \pm 0.49^{\mathrm{aE}}$ & $1.91 \pm 0.12^{\mathrm{dE}}$ & $3.83 \pm 0.36^{\mathrm{cF}}$ \\
\hline \multirow[t]{2}{*}{ Thyme } & $20.17 \pm 0.22^{\mathrm{cBCD}}$ & $23.5 \pm 0.63^{\mathrm{aC}}$ & $11.88 \pm 0.38^{\mathrm{eBC}}$ & $18.4 \pm 0.65^{\mathrm{dC}}$ & $21.73 \pm 0.38^{\mathrm{bB}}$ & $21 \pm 0.14^{\mathrm{bB}}$ \\
\hline & \multicolumn{6}{|l|}{ TFC mg QE/g } \\
\hline Allspice & $2.51 \pm 0.18^{\mathrm{bF}}$ & $2.85^{*} \pm 0.07^{\mathrm{aE}}$ & $2.29 \pm 0.12^{\mathrm{bE}}$ & $3.11 \pm 0.27^{\mathrm{aE}}$ & $1.54 \pm 0.07^{\mathrm{dFG}}$ & $1.94 \pm 0.07^{\mathrm{cEF}}$ \\
\hline Basil & $3.19 \pm 0.13^{\mathrm{eE}}$ & $3.94 \pm 0.04^{\mathrm{cD}}$ & $5.37 \pm 0.30^{\mathrm{bC}}$ & $7.11 \pm 0.11^{\mathrm{aD}}$ & $3.25 \pm 0.16^{\mathrm{deD}}$ & $3.59 \pm 0.35^{\mathrm{cdD}}$ \\
\hline Bay leaf & $3.57 \pm 0.47^{\mathrm{cE}}$ & $3.84^{*} \pm 0.12^{\mathrm{cD}}$ & $9.58 \pm 0.44^{\mathrm{bB}}$ & $10.99 \pm 0.28^{\mathrm{aC}}$ & $1.76 \pm 0.09^{\mathrm{dEF}}$ & $1.95 \pm 0.08^{\mathrm{dEF}}$ \\
\hline Black seed & $0.77 \pm 0.12^{\mathrm{bcdHI}}$ & $0.98^{*} \pm 0.05^{\mathrm{bcG}}$ & $0.47 \pm 0.07^{\mathrm{dH}}$ & $0.59 \pm 0.03^{\mathrm{cdG}}$ & $1.04 \pm 0.03^{\mathrm{bGH}}$ & $1.61 \pm 0.50^{\mathrm{aFG}}$ \\
\hline Cardamom & $0.58 \pm 0.01^{\mathrm{cdHI}}$ & $0.65^{*} \pm 0.04^{\mathrm{aGH}}$ & $0.49 \pm 0.02^{\mathrm{eH}}$ & $0.56 \pm 0.02^{\mathrm{dG}}$ & $0.64 \pm 0.01^{\mathrm{abHI}}$ & $0.61 \pm 0.01^{\mathrm{bcH}}$ \\
\hline Carraway & $1.75 \pm 0.05^{\mathrm{bG}}$ & $1.92^{*} \pm 0.07^{\mathrm{aF}}$ & $1.19 \pm 0.05^{\mathrm{eFG}}$ & $1.3 \pm 0.06^{\mathrm{dF}}$ & $1.52 \pm 0.06^{\mathrm{cFG}}$ & $1.78 \pm 0.07^{\mathrm{bEF}}$ \\
\hline Cloves & $31.58 \pm 0.70^{\mathrm{aA}}$ & $26.22^{*} \pm 0.78^{\mathrm{bA}}$ & $18.36 \pm 0.99^{\mathrm{dA}}$ & $13.89 \pm 1.04^{\mathrm{eA}}$ & $27.78 \pm 1.09^{\mathrm{bA}}$ & $22.7 \pm 0.86^{\mathrm{cA}}$ \\
\hline Garlic & $8.84 \pm 0.30^{\mathrm{aB}}$ & $0.39 \pm 0.07^{\mathrm{cH}}$ & $0.28 \pm 0.02^{\mathrm{cH}}$ & $0.41 \pm 0.04^{\mathrm{cG}}$ & $2.14 \pm 0.14^{\mathrm{bE}}$ & $0.43 \pm 0.02^{\mathrm{cH}}$ \\
\hline Nutmeg & $0.87 \pm 0.03^{\mathrm{bcH}}$ & $0.89^{*} \pm 0.01^{\mathrm{bG}}$ & $0.71 \pm 0.03^{\mathrm{cdGH}}$ & $0.83 \pm 0.00^{\mathrm{bcFG}}$ & $0.59 \pm 0.01^{\mathrm{dHI}}$ & $1.15 \pm 0.23^{\mathrm{aG}}$ \\
\hline Onion & $0.31 \pm 0.05^{\mathrm{abI}}$ & $0.34 \pm 0.02^{\mathrm{aH}}$ & $0.27 \pm 0.01^{\mathrm{bH}}$ & $0.31 \pm 0.01^{\mathrm{abG}}$ & $0.28 \pm 0.00^{\mathrm{bI}}$ & $0.32 \pm 0.03^{\mathrm{abH}}$ \\
\hline Oregano & $5.46 \pm 0.17^{\mathrm{bD}}$ & $6.82 \pm 0.35^{\mathrm{aC}}$ & $4.45 \pm 0.45^{\mathrm{cdD}}$ & $6.72 \pm 0.38^{\mathrm{aD}}$ & $4.14 \pm 0.27^{\mathrm{dC}}$ & $4.85 \pm 0.34^{\mathrm{cC}}$ \\
\hline Rosemary & $0.84 \pm 0.06^{\mathrm{dH}}$ & $1.57 \pm 0.29^{\mathrm{cF}}$ & $1.48 \pm 0.10^{\mathrm{cF}}$ & $3.1 \pm 0.31^{\mathrm{aE}}$ & $0.63 \pm 0.08^{\mathrm{dHI}}$ & $2.31 \pm 0.12^{\mathrm{bE}}$ \\
\hline Thyme & $6.67 \pm 0.35^{\mathrm{cC}}$ & $8.1 \pm 0.18^{\mathrm{bB}}$ & $5.72 \pm 0.47^{\mathrm{dC}}$ & $11.87 \pm 0.16^{\mathrm{aB}}$ & $6.53 \pm 0.22^{\mathrm{cB}}$ & $7.04 \pm 0.09^{\mathrm{cB}}$ \\
\hline
\end{tabular}

$G A E$ gallic acid equivalent, $Q E$ quercetin equivalent

$\mathrm{a}, \mathrm{b}, \mathrm{c}, \mathrm{d}, \mathrm{e}$ Means $(\mathrm{n}=3)$ with the same superscripts within the same row do not differ significantly $(\mathrm{p}>0.05)$

A, B, C, D, E, F, G, H, IMeans ( $=3$ ) with the same superscripts within the same column (for each method separately) do not differ significantly $(\mathrm{p}>0.05)$

*Data shown previously in [21] 


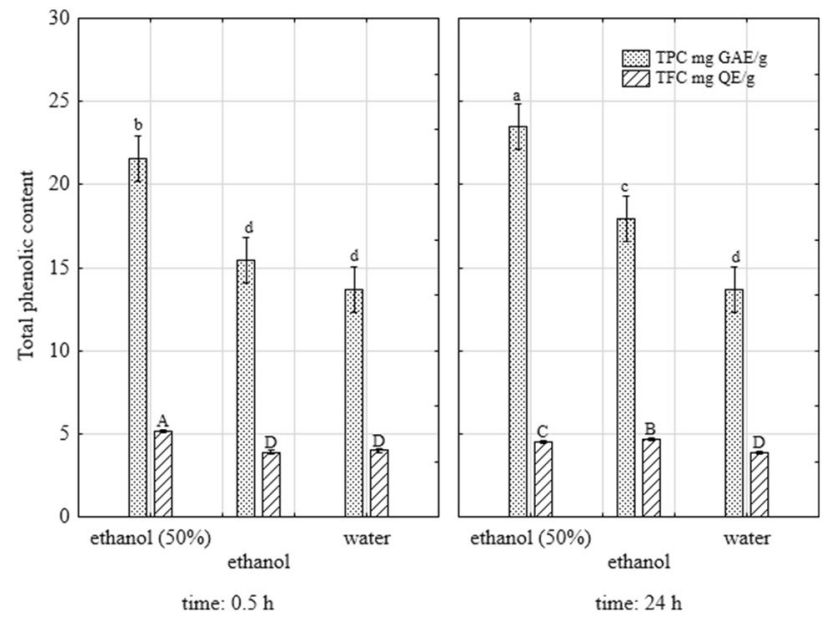

Fig. 1 Effects of time and solvent on total polyphenol content (TPC) and total flavonoid content (TFC) of herb and spice extracts. Vertical bars denote 0.95 confidence interval; means within the same method with the same superscript letter are not significantly different $(\mathrm{p}>0.05$, Duncan's test)

plant material, the mean phenolic content of the extracts increased in the following order of solvents: water $<$ ethanol $<50 \%$ ethanol and equaled, respectively, to $13.7,16.7$ and $22.5 \mathrm{mg} \mathrm{GAE} / \mathrm{g}$. This indicates the importance of choosing the appropriate solvent for the extraction procedure. Although phenolic compounds with the high number of hydroxyl groups and glycoside moieties should be good dissolved in water of high polarity [4], water extracts of herbs and spices were characterized by the lowest TPC among tested samples (Fig. 1). On the other hand, the use of pure alcohol as solvent for phenolic extraction could increase the yield of extraction in comparison to water as it was shown by others [24], because of the degradation of lipid cell membranes and release of the compounds from plant cell [4]. However, the polarity of pure alcohol solvent could be too low to extract most of phenolic compounds as it was observed in this study (Fig. 1). Generally, increasing the polarity of the ethanol by adding water is better for recovery of the phenolic compounds, since higher polarity enables the breakage of hydrogen bonds in polyphenols structure and improves their solubility in organic solvents [2]. Our findings are in agreement with the studies of Przygodzka et al. [7], who reported that water-ethanol (1:1) mixture was better solvent for extraction of TPC from allspice, clove and some other aromatic spices, and also Alcântara et al. [25], as the highest efficiency of TPC extraction from chia seeds was observed in the binary water-ethanol solvent in comparison to water and ethanol solvents alone. As reported by others [24, 26, 27] water was the least efficient solvent when considering the polyphenol extraction from plant material.

Time of extraction also significantly affected TPC. The highest content of phenolic compounds, expressed as TPC value were observed after $24 \mathrm{~h}$ of extraction for each solvent, regardless of plant material (Fig. 1). Although, some researchers reported that prolonged extraction led to a decrease in phenolic content of extracts as oxidation of the compounds could occur by the increasing time of extraction [28], others [5, 29] showed that prolonged sample exposure in the solvent allowed the compounds to migrate to solvent from plant material as observed in this study.

When taking into consideration both effects solvent and extraction time for individual spice or herb, 8 out of 13 samples had the highest TPC values after extraction with the $50 \%$ aqueous ethanol, namely allspice, basil, clove, oregano and thyme after $24 \mathrm{~h}$, and bay leaf, garlic and nutmeg after $0.5 \mathrm{~h}$ of extraction. The exceptions were: onion with the highest TPC in water (TPC $=7.23 \mathrm{mg} \mathrm{GAE} / \mathrm{g})$ and cardamom and rosemary, both with the highest mean TPC in ethanol equaled to, respectively, 1.69 and $5.69 \mathrm{mg}$ GAE/g DW. Surprisingly, in the case of caraway, no statistically significant difference was found between the TPC values obtained in $50 \%$ ethanol (TPC $=2.39 \mathrm{mg} \mathrm{GAE} / \mathrm{g}$ ) and water (TPC $=2.43 \mathrm{mg} \mathrm{GAE} / \mathrm{g}$ ). Also, the lack of significant difference was observed between the TPC values of black seed after extraction in $50 \%$ ethanol $(2.46 \mathrm{mg} \mathrm{GAE} / \mathrm{g})$ and pure ethanol (2.61 mg GAE/g). These various levels of TPC from the same spice as a result of different solvent used for the extraction might be due to the profile of phenolic compounds of the extract and the properties of the compounds including hydrophobicity. Table 2 includes the literature review on phenolics identified in various extracts of spices and herbs $[8,30-38]$ as well as the values of $\log P$ of the individual compounds [39-45]. We could find that rosemary had high contribution of phenolics with a relatively high hydrophobicity, namely rosemarinic acid [8], which might partly explain the highest level of its TPC in ethanol nor in water. Similarly, clove contained a substantial amount of hydrophobic compound-eugenol [31], thus its TPC after only water extraction was much lower than in ethanol-containing solvents. In contrast, spice like caraway with high pool of phenolic acids in total phenolic content, like chlorogenic acid [30], with a relatively low hydrophobicity, generally showed the highest TPC values in water and/or aqueous solvents.

The amount of phenolics varied widely depending on plant materials and the highest TPC values were observed for clove extracts in all extraction conditions (Table 1). TPC values for cloves ranged from $79 \mathrm{mg} \mathrm{GAE} / \mathrm{g}$ in water (24 h) to $167 \mathrm{mg}$ GAE/g in 50\% ethanol $(24 \mathrm{~h})$. Our results are in agreement with the findings of Przygodzka et al. [7], who reported that clove water-ethanol $(1: 1)$ extract was the one with the highest TPC content of $141 \mathrm{mg} \mathrm{GAE} / \mathrm{g}$ DW, Elhussein et al. [31] as water-methanol (1:1) extract of clove contained the phenolic compounds with the concentration of $201 \mathrm{mg} \mathrm{GAE} / \mathrm{g} \mathrm{DW}$ and Asseffa et al. [9] who found TPC value of $80 \%$ aqueous methanol clove 
Table $2 \log \mathrm{P}$ of the individual phenolic compounds and phenolics identified in various herbs and spices (data collected from the literature)

\begin{tabular}{|c|c|c|c|}
\hline Phenolic compounds & $\log \mathrm{P}$ & Spices/herbs & Ref \\
\hline$p$-Hydroxybenzoic acid & 2.27 [39] & Bay leaf, caraway, nutmeg, onion, oregano, rosemary, thyme & [8] [30] [33] \\
\hline Protocatechuic acid & $\begin{array}{l}0.82[39] \\
0.76[40]\end{array}$ & Basil, bay leaf, nutmeg, onion, oregano, rosemary, thyme & {$[8][30][38][33][35]$} \\
\hline Gallic acid & $\begin{array}{l}0.47[39] \\
0.91[41]\end{array}$ & Black seed, clove, thyme & {$[35][37]$} \\
\hline Syringic acid & $\begin{array}{l}0.95[39] \\
1.11[40]\end{array}$ & Caraway, bay leaf, nutmeg, onion, oregano, thyme, rosemary & {$[8][30][33]$} \\
\hline$p$-Coumaric acid & $1.54[39]$ & Basil, bay leaf, black seed, caraway, garlic, onion, oregano, rosemary, thyme & {$[8][30][33][35][36]$} \\
\hline Caffeic acid & $\begin{array}{l}1.15[39] \\
1.29[40] \\
2.47[41]\end{array}$ & $\begin{array}{l}\text { Basil, bay leaf, black seed, caraway, cardamom, Garlic, nutmeg, onion, } \\
\text { oregano, rosemary, thyme }\end{array}$ & [8] [30] [33] [34][34] \\
\hline Ferulic acid & $1.42[39]$ & Bay leaf, black seed, caraway, nutmeg, onion, oregano, rosemary, thyme & {$[8][30][32][33][36]$} \\
\hline Rosmarinic acid & 2.07 [39] & Basil, bay leaf, caraway, nutmeg, oregano, rosemary, thyme & [8] [30] [35] \\
\hline Chlorogenic acid & $0.69[41]$ & Bay leaf, black seed, caraway, nutmeg, onion, oregano, rosemary, thyme & [8] [30] [33] [34] \\
\hline Quercetin & $\begin{array}{l}2.74[41] \\
1.48[42] \\
1.82[43]\end{array}$ & Black seed, caraway, clove, garlic, nutmeg, onion, oregano, rosemary, thyme & [8] [30] [32] [33] [35] [37] \\
\hline Kaempferol & $\begin{array}{l}2.67[41] \\
3.11[43]\end{array}$ & Black seed, caraway, clove, garlic, onion, oregano & [32] [33] [34] [35] [36][36] \\
\hline Rutin & $-1.3[42]$ & Bay leaf, black seed, nutmeg & {$[38][37]$} \\
\hline Catechin & $0.86[44]$ & $\begin{array}{l}\text { Basil, caraway, nutmeg, onion, } \\
\text { rosemary }\end{array}$ & {$[30][33][35]$} \\
\hline Eugenol & $2.49[45]$ & Cloves & [31] \\
\hline
\end{tabular}

extract equaled to $161 \mathrm{mg} \mathrm{GAE} / \mathrm{g}$ DW. In this study, other herb and spice extracts showed, significantly lower TPC values in comparison to cloves.

Allspice was the second most phenolic-rich extract with the TPC values about 4.5-6-fold lower than that of cloves, whereas caraway, cardamom and black seed showed the lowest TPC values, from $1 \mathrm{mg} \mathrm{GAE} / \mathrm{g}$ to, $2.6 \mathrm{mg} \mathrm{GAE} / \mathrm{g}$. Others [7, 9] indicated allspice extract as a rich source of phenolic compounds and the TPC values obtained by them were much higher than in our study, namely for ethanol-water extract TPC was about $150 \mathrm{mg}$ GAE/g DW [7], whereas for $80 \%$ methanol extract TPC was $73 \mathrm{mg} \mathrm{GAE} / \mathrm{g}$ DW [9]. It was difficult to compare directly the results on TPC for all tested herbs and spices, since various extraction procedures were applied. Generally, other authors [6-9, 30-32, 38, 46-48] reported higher TPC values for basil, bay leaf, caraway, cardamom, garlic, nutmeg, onion, oregano, rosemary and thyme in comparison to our results. Although, Vallverdú-Querald et al. [8] found $50 \%$ ethanol extracts of thyme, oregano and bay leaf to have TPC values lower (respectively, 3.4, 2.2, $1.1 \mathrm{mg}$ GAE/g DW) than in this study. Lower TPC values in comparison to our results were also reported by Nikolic et al. [6] for $80 \%$ aqueous methanol extracts of thyme and basil, by Park et al. [27] for water and methanol extracts of onion and by Yang et al. [33] for 30\% ethanol extracts of garlic and onion.
Regardless of the time and solvent type, the TPC values of the plant samples decreased in the following order: clove $>>>$ allspice $>$ thyme $\approx$ bay leaf $\geq$ oregano $>$ basil $>$ onion $\approx$ nutmeg $\approx$ rosemary $\approx$ garlic $\geq$ black seed $\approx$ caraway $\approx$ cardamom. The same order was noticed in this study after extraction with $50 \%$ aqueous ethanol solvent. Previously, similar relations was shown by Assefa et al. [9] as followed: clove $>$ allspice $>$ thyme $>$ oregano $\geq$ rosemary $\geq$ bay leaf $>$ basil $>$ nutmeg $>$ cardamom $>$ caraway. It is worthy to stress out that the studies on the phenolic content of black seed are rather scarce. Black seed was previously shown to have TPC values of $2.79 \mathrm{mg} \mathrm{GAE} / \mathrm{g} \mathrm{DW}$ after extraction with 30\% ethanol [49], $2.65 \mathrm{mg}$ GAE/g after water extraction and 2.93 after extraction with $70 \%$ aqueous methanol [34] which is similar to our results.

The aluminum chloride method was performed to analyze flavonoid content of the samples. In this method, especially flavones and flavonols could make a stable complex with $\mathrm{AlCl}_{3}$ [50]. TFC parameter was significantly affected by the solvent type and plant material. The effect of time was negligible from the statistical point of view (Table 1, Fig. 1). The TFC values of tested spices and herbs varied widely from $31.6 \mathrm{mg} \mathrm{QE} / \mathrm{g}$ for clove water-ethanol extract to 0.27 and $0.28 \mathrm{mg} \mathrm{QE} / \mathrm{g}$ for, respectively, onion and garlic ethanol extracts. Based on the results obtained it is hard to point out the best solvent for flavonoid extraction. The highest values of TFC were noted for caraway, clove, garlic and 
oregano after extraction with 50\% ethanol; allspice, basil, bay leaf rosemary and thyme after extraction with ethanol alone and black seed and nutmeg after extraction with pure water. Exceptions were cardamom and onion. In case of cardamom, both solvents, $50 \%$ ethanol and pure water could be recommended for the extraction, whereas no statistically significant differences between mean TFC values of onion after extraction by either solvent were noted. Our results contradicted the data presented by Przygodzka et al. [7] since the highest TFC values were previously observed in ethanol extracts of clove and cardamom and in 50\% ethanol extracts of allspice and nutmeg [7]. The values of TFC for cardamom, bay leaf, basil, cloves, black seed and garlic reported by others $[9,33,49]$ differed from the ones obtained in this study. Only the values of TFC noted by Assefa et al. [9] for $80 \%$ methanol extracts of allspice, nutmeg, oregano, rosemary were similar to TFC values for ethanol extracts shown in Table 1. The results reported by Yang et al. [33] for 30\% ethanol extracts of onion $(\mathrm{TFC}=0.31 \mathrm{mg} \mathrm{QE} / \mathrm{g} \mathrm{DW})$ were also in accordance to our data.

A wide range of TPC and TFC values for the spices and herbs tested in this study indicated the huge diversity of the phenolic compounds which could react with the FCR and aluminum chloride, respectively. Although the order of extracts differed when comparing both parameters, high $r$ Pearson's coefficient was reported for the correlation between TFC and TPC (Table 3).

\section{Antioxidant activity}

It is well-known from previous studies that the antioxidant activity of plant extracts cannot be discussed based on the results of a single assay $[23,51]$. Therefore, in this study the effects of solvent and time of extraction on the antioxidant activity of herb and spice extracts were evaluated using three different methods, namely, DPPH, ABTS and FRAP. The significant effects $(\mathrm{p} \leq 0.05)$ of both: solvent and time of extraction on the antioxidant activity of extracts were observed. The $50 \%$ ethanol extracts were more potent antioxidants than both, ethanol alone and water extracts (Fig. 2).

Table 3 Pearson's correlation coefficients ( $\mathrm{r}$ ) between antioxidant activity (DPPH, ABTS, FRAP), total polyphenol content (TPC) and total flavonoid content (TFC)

\begin{tabular}{llllll}
\hline & DPPH & ABTS & FRAP & TPC & TFC \\
\hline DPPH & 1 & 0.99 & 0.95 & 0.95 & 0.82 \\
ABTS & & 1 & 0.97 & 0.97 & 0.83 \\
FRAP & & & 1 & 0.98 & 0.84 \\
TPC & & & & 1 & 0.87 \\
TFC & & & & & 1 \\
\hline
\end{tabular}

All correlation coefficients were statistically significant at $\mathrm{p}=0.05$
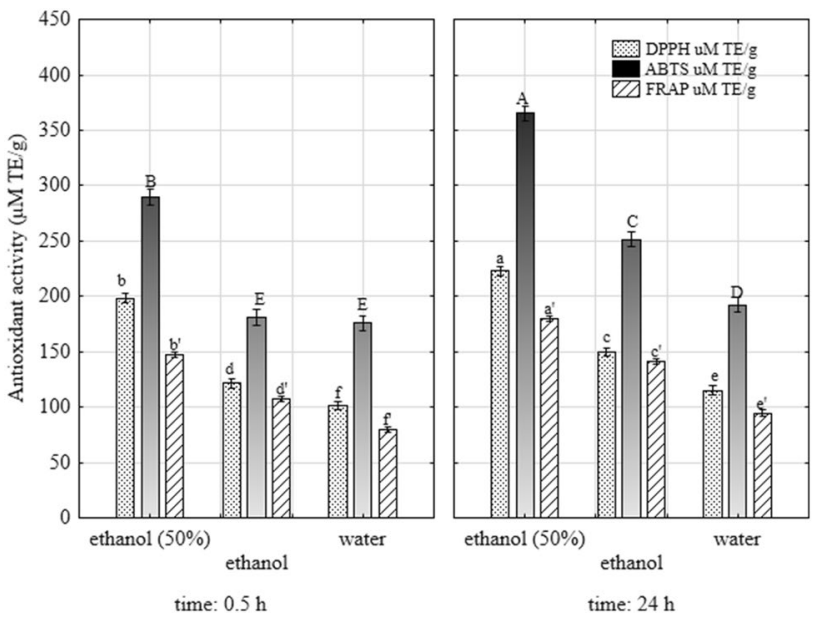

Fig. 2 Effects of time and solvent on the antioxidant activity of herb and spice extracts expressed by the three methods: DPPH, ABTS and FRAP. Vertical bars denote 0.95 confidence interval; means within the same method with the same superscript letter are not significantly different ( $p>0.05$, Duncan's test)

The mean antioxidant activity of all extracts after $0.5 \mathrm{~h}$ of extraction in 50\% ethanol equaled to 198, 290 and $147 \mu \mathrm{mol}$ TE/g for DPPH, ABTS and FRAP assays, respectively (Fig. 2). After $24 \mathrm{~h}$ of extraction the mean antioxidant activity of all extracts increased, respectively, up to 227, 365 and $180 \mu \mathrm{mol} \mathrm{TE} / \mathrm{g}$ for, respectively, DPPH, ABTS and FRAP assays. The antioxidant activity of the extracts differs significantly between various plant materials $(\mathrm{p} \leq 0.05)$ (Table 4$)$. When considering the values of antioxidant activity for the individual extracts most of the samples showed the highest antioxidant activity after extraction with $50 \%$ ethanol (Table 4) which is in agreement to the previous study [7].

Clove extracts showed the highest $\mathrm{ABTS}^{\bullet+}$ scavenging activity ranging from 1020 to $2496 \mu \mathrm{mol} \mathrm{TE} / \mathrm{g}$, DPPH ${ }^{\bullet}$ scavenging activity ranging from 547 to $1443 \mu \mathrm{mol} \mathrm{TE} / \mathrm{g}$ as well as FRAP values which ranged from 447 to $1411 \mu \mathrm{mol} \mathrm{TE} / \mathrm{g}$, after extraction with, respectively, water and $50 \%$ ethanol in water. The second most active extract was allspice with 2.3-3.4, 1.9-3.8 and 3.0-7.5 times lower antioxidant activity (measured by, respectively, ABTS, DPPH and FRAP methods in water and 50\% ethanol) when comparing to cloves. Bay leaf also showed significantly lower antioxidant activity than cloves by about 4.8-10.1 times for ABTS, 3.3-6.2 times for DPPH and 5.5-8.2 times for FRAP assays. Our results are in agreement with the studies of Przygodzka et al. [7] who reported similar radical scavenging activity against $\mathrm{ABTS}^{\bullet+}$ for the $50 \%$ aqueous ethanol extracts of cloves and allspice after short-time extraction. However, after extraction with only ethanol the ABTS values of cloves and allspice found by others [7] were significantly lower than the values shown in this study. Lu et al. [38], who studied the antioxidant activity of bay leaf and nutmeg after $24 \mathrm{~h}$ of 
Table 4 Antioxidant activity of extracts determined by the DPPH, ABTS, and FRAP assays

\begin{tabular}{|c|c|c|c|c|c|c|}
\hline \multirow[t]{2}{*}{ Time of extraction } & \multicolumn{2}{|l|}{$50 \%$ Ethanol } & \multicolumn{2}{|l|}{ Ethanol } & \multicolumn{2}{|l|}{ Water } \\
\hline & $0.5 \mathrm{~h}$ & $24 \mathrm{~h}$ & $0.5 \mathrm{~h}$ & $24 \mathrm{~h}$ & $0.5 \mathrm{~h}$ & $24 \mathrm{~h}$ \\
\hline Extracts & \multicolumn{6}{|l|}{$\mathrm{DPPH} \mu \mathrm{mol} \mathrm{TE} / \mathrm{g}$} \\
\hline Allspice & $613.38 \pm 9.50^{\mathrm{aB}}$ & $555.06^{*} \pm 24.22^{\mathrm{bB}}$ & $388.65 \pm 13.04^{\mathrm{dB}}$ & $403.47 \pm 11.36^{\mathrm{eB}}$ & $214.85 \pm 11.47^{\mathrm{cB}}$ & $171.9 \pm 3.92^{\mathrm{cB}}$ \\
\hline Basil & $124.94 \pm 5.24^{\mathrm{abE}}$ & $134.67 \pm 2.28^{\mathrm{aF}}$ & $31.52 \pm 2.00^{\mathrm{dDE}}$ & $37.65 \pm 1.93^{\mathrm{dF}}$ & $119.53 \pm 16.64^{\mathrm{bD}}$ & $84.51 \pm 1.00^{\mathrm{cD}}$ \\
\hline Bay leaf & $234.59 \pm 14.07^{\mathrm{bC}}$ & $231.94 * \pm 1.45^{\mathrm{bD}}$ & $185.83 \pm 8.91^{\mathrm{cC}}$ & $249.66 \pm 3.26^{\mathrm{aC}}$ & $98.37 \pm 2.03^{\mathrm{eD}}$ & $130.15 \pm 7.34^{\mathrm{dC}}$ \\
\hline Black seed & $7.95 \pm 1.60^{\mathrm{aFG}}$ & $7.59^{*} \pm 0.84^{\mathrm{abH}}$ & $5.13 \pm 0.15^{\mathrm{cE}}$ & $6.3 \pm 0.13^{\mathrm{bcG}}$ & $3.1 \pm 0.16^{\mathrm{dE}}$ & $2.84 \pm 0.15^{\mathrm{dE}}$ \\
\hline Cardamom & $5.14 \mathrm{~s} \pm 0.35^{\mathrm{aG}}$ & $5.45^{*} \pm 0.35^{\mathrm{aH}}$ & $3.29 \pm 0.05^{\mathrm{cE}}$ & $4.06 \pm 0.05^{\mathrm{bG}}$ & $3.46 \pm 0.11^{\mathrm{cE}}$ & $3.36 \pm 0.53^{\mathrm{cE}}$ \\
\hline Carraway & $16.77 \pm 0.22^{\mathrm{bFG}}$ & $20.17^{*} \pm 0.60^{\mathrm{aGH}}$ & $12.23 \pm 0.20^{\mathrm{dE}}$ & $15.26 \pm 0.02^{\mathrm{cFG}}$ & $14.72 \pm 0.88^{\mathrm{cE}}$ & $17.1 \pm 1.14^{\mathrm{bE}}$ \\
\hline Cloves & $1141.34 \pm 37.67^{\mathrm{bA}}$ & $1443.35^{*} \pm 16.84^{\mathrm{aA}}$ & $779.23 \pm 58.98^{\mathrm{cA}}$ & $833.55 \pm 51.32^{\mathrm{cA}}$ & $546.88 \pm 38.59^{\mathrm{eA}}$ & $645.88 \pm 42.60^{\mathrm{dA}}$ \\
\hline Garlic & $7.04 \pm 0.90^{\mathrm{bFG}}$ & $14.81 \pm 1.96^{\mathrm{aGH}}$ & $15.94 \pm 0.19^{\mathrm{aE}}$ & $4.88 \pm 0.24^{\mathrm{cG}}$ & $2.1 \pm 0.06^{\mathrm{dE}}$ & $1.83 \pm 0.11^{\mathrm{dE}}$ \\
\hline Nutmeg & $27.65 \pm 1.11^{\mathrm{aF}}$ & $22.22^{*} \pm 0.15^{\mathrm{bH}}$ & $22.07 \pm 1.07^{\mathrm{bE}}$ & $21.48 \pm 0.37^{\mathrm{bFG}}$ & $8.69 \pm 0.03^{\mathrm{cE}}$ & $7.55 \pm 0.41^{\mathrm{cE}}$ \\
\hline Onion & $5.36 \pm 0.22^{\mathrm{abG}}$ & $5.74 \pm 0.28^{\mathrm{aH}}$ & $3.77 \pm 0.51^{\mathrm{cE}}$ & $2.96 \pm 0.86^{\mathrm{dG}}$ & $4.86 \pm 0.13^{\mathrm{bE}}$ & $4.92 \pm 0.19^{\mathrm{abE}}$ \\
\hline Oregano & $192.69 \pm 2.16^{\mathrm{aD}}$ & $171.66 \pm 5.82^{\mathrm{bE}}$ & $59.12 \pm 2.87^{\mathrm{dD}}$ & $105.32 \pm 3.16^{\mathrm{cE}}$ & $115.43 \pm 7.78^{\mathrm{cD}}$ & $170.91 \pm 12.04^{\mathrm{bB}}$ \\
\hline Rosemary & $12.29 \pm 0.58^{\mathrm{dFG}}$ & $50.36 \pm 3.59^{\mathrm{cG}}$ & $19.95 \pm 0.28^{\mathrm{dE}}$ & $105.87 \pm 6.84^{\mathrm{aE}}$ & $12.71 \pm 0.53^{\mathrm{dE}}$ & $69.28 \pm 11.40^{\mathrm{bD}}$ \\
\hline \multirow[t]{2}{*}{ Thyme } & $186.98 \pm 3.45^{\mathrm{bD}}$ & $278.33 \pm 16.23^{\mathrm{aC}}$ & $52.17 \pm 3.42^{\mathrm{eD}}$ & $155.86 \pm 0.82^{\mathrm{dD}}$ & $173.83 \pm 2.37^{\mathrm{cC}}$ & $186.23 \pm 2.47^{\mathrm{bB}}$ \\
\hline & \multicolumn{6}{|l|}{ ABTS $\mu \mathrm{mol} \mathrm{TE} / \mathrm{g}$} \\
\hline Allspice & $844.83 \pm 44.98^{\mathrm{aB}}$ & $815.37 * * \pm 20.85^{\mathrm{aB}}$ & $548.71 \pm 12.65^{\mathrm{bB}}$ & $561.29 \pm 10.99^{\mathrm{bB}}$ & $300.66 \pm 11.22^{\mathrm{cB}}$ & $327.22 \pm 30.52^{\mathrm{cB}}$ \\
\hline Basil & $134.87 \pm 3.90^{\mathrm{cD}}$ & $244.89 \pm 8.69^{\mathrm{aE}}$ & $35.05 \pm 3.45^{\mathrm{eDEF}}$ & $49.32 \pm 2.96^{\mathrm{dE}}$ & $145.88 \pm 8.87^{\mathrm{bE}}$ & $146.15 \pm 4.65^{\mathrm{bD}}$ \\
\hline Bay leaf & $285.86 \pm 5.63^{\mathrm{bC}}$ & $280.03^{* *} \pm 21.51^{\mathrm{bD}}$ & $130.04 \pm 4.05^{\mathrm{dC}}$ & $343.81 \pm 14.05^{\mathrm{aC}}$ & $173.46 \pm 11.16^{\mathrm{CDE}}$ & $165.95 \pm 8.02^{\mathrm{cD}}$ \\
\hline Black seed & $26.15 \pm 1.28^{\mathrm{bEF}}$ & $33.06^{* *} \pm 2.79^{\mathrm{aGH}}$ & $12.51 \pm 0.76^{\mathrm{dF}}$ & $16.13 \pm 2.63^{\mathrm{cE}}$ & $32.67 \pm 0.16^{\mathrm{aFG}}$ & $8.67 \pm 0.50^{\mathrm{eG}}$ \\
\hline Cardamom & $12.59 \pm 0.34^{\mathrm{aF}}$ & $12.93^{* *} \pm 0.46^{\mathrm{aH}}$ & $7.32 \pm 0.12^{\mathrm{cF}}$ & $9.96 \pm 0.33^{\mathrm{bE}}$ & $9.81 \pm 0.24^{\mathrm{bG}}$ & $10.31 \pm 0.83^{\mathrm{bG}}$ \\
\hline Carraway & $30.52 \pm 0.59^{\mathrm{bEF}}$ & $35.37 * * \pm 0.39^{\mathrm{aGH}}$ & $19.71 \pm 1.09^{\mathrm{eEF}}$ & $24.58 \pm 1.87^{\mathrm{dE}}$ & $27.78 \pm 1.63^{\mathrm{cFG}}$ & $30.03 \pm 2.22^{\mathrm{bcFG}}$ \\
\hline Cloves & $1909 \pm 80.94^{\mathrm{bA}}$ & $2495.85^{* *} \pm 31.41^{\mathrm{aA}}$ & $1309.09 \pm 51.80 \mathrm{dA}$ & $1652.97 \pm 109.58^{\mathrm{cA}}$ & $1020.45 \pm 57.04^{\mathrm{eA}}$ & $1184.09 \pm 65.97^{\mathrm{dA}}$ \\
\hline Garlic & $47.77 \pm 1.78^{\mathrm{dEF}}$ & $76.87 \pm 4.68^{\mathrm{bF}}$ & $7.97 \pm 0.14^{\mathrm{fF}}$ & $17.52 \pm 2.48^{\mathrm{eE}}$ & $57.91 \pm 0.96^{\mathrm{cF}}$ & $93.45 \pm 9.29^{\mathrm{aE}}$ \\
\hline Nutmeg & $55.39 \pm 1.51^{\mathrm{aEF}}$ & $44.8^{* *} \pm 1.93 \mathrm{bG}$ & $47.36 \pm 1.97^{\mathrm{bDE}}$ & $44.47 \pm 1.30^{\mathrm{bE}}$ & $25.27 \pm 2.43^{\mathrm{cG}}$ & $24.71 \pm 2.04^{\mathrm{cG}}$ \\
\hline Onion & $28.13 \pm 0.63^{\mathrm{aEF}}$ & $31.52 \pm 1.34^{\mathrm{aGH}}$ & $19.09 \pm 1.15^{\mathrm{bEF}}$ & $20.56 \pm 2.65^{\mathrm{bE}}$ & $28.29 \pm 2.34^{\mathrm{aFG}}$ & $30.06 \pm 1.87^{\mathrm{aFG}}$ \\
\hline Oregano & $252.95 \pm 6.77^{\mathrm{bC}}$ & $343.1 \pm 0.80^{\mathrm{aC}}$ & $137.41 \pm 10.91^{\mathrm{eC}}$ & $242.47 \pm 10.33^{\mathrm{bD}}$ & $178.27 \pm 8.87^{\mathrm{dD}}$ & $204.23 \pm 11.63^{\mathrm{cC}}$ \\
\hline Rosemary & $64.61 \pm 1.92^{\mathrm{aE}}$ & $46.59 \pm 2.89^{\mathrm{bG}}$ & $20.18 \pm 0.71^{\mathrm{dF}}$ & $31.15 \pm 1.48^{\mathrm{cE}}$ & $22.58 \pm 1.28^{\mathrm{dG}}$ & $65 \pm 6.13^{\mathrm{aEF}}$ \\
\hline \multirow[t]{2}{*}{ Thyme } & $72.06 \pm 3.08^{\mathrm{dE}}$ & $288.07 \pm 4.04^{\mathrm{aD}}$ & $60.39 \pm 6.74^{\mathrm{eD}}$ & $253.99 \pm 7.09^{\mathrm{bD}}$ & $261.58 \pm 7.35^{\mathrm{bC}}$ & $208.53 \pm 1.74^{\mathrm{cC}}$ \\
\hline & \multicolumn{6}{|l|}{ FRAP $\mu \mathrm{mol} \mathrm{TE} / \mathrm{g}$} \\
\hline Allspice & $140.06 \pm 20.09^{\mathrm{cD}}$ & $347.81 * \pm 2.15^{\mathrm{aB}}$ & $138.94 \pm 2.96^{\mathrm{cB}}$ & $176.49 \pm 21.26^{\mathrm{bB}}$ & $147.69 \pm 5.98^{\mathrm{cB}}$ & $139.28 \pm 5.33^{\mathrm{cB}}$ \\
\hline Basil & $133.29 \pm 4.82^{\mathrm{aD}}$ & $111.48 \pm 4.19^{\mathrm{bE}}$ & $26.42 \pm 4.33^{\mathrm{eEF}}$ & $47.7 \pm 1.18^{\mathrm{dE}}$ & $85.25 \pm 2.28^{\mathrm{cD}}$ & $90.31 \pm 8.04^{\mathrm{cC}}$ \\
\hline Bay leaf & $158.68 \pm 2.55^{\mathrm{bC}}$ & $158.84^{*} \pm 2.51^{\mathrm{bC}}$ & $153.6 \pm 4.78^{\mathrm{bB}}$ & $187.84 \pm 7.96^{\mathrm{aB}}$ & $132.34 \pm 5.20^{\mathrm{cC}}$ & $75.92 \pm 2.75^{\mathrm{dD}}$ \\
\hline Black seed & $10.25 \pm 0.23^{\mathrm{bEF}}$ & $14.67 * \pm 0.78^{\mathrm{aGH}}$ & $8.29 \pm 0.40^{\mathrm{bFG}}$ & $13.57 \pm 3.56^{\mathrm{aG}}$ & $4.55 \pm 0.30^{\mathrm{cG}}$ & $8.33 \pm 0.21^{\mathrm{bG}}$ \\
\hline Cardamom & $4.97 \pm 0.19^{\mathrm{cF}}$ & $5.46^{*} \pm 0.17^{\mathrm{bGH}}$ & $5.93 \pm 0.43^{\mathrm{bFG}}$ & $6.98 \pm 0.16^{\mathrm{aG}}$ & $3.52 \pm 0.21^{\mathrm{dG}}$ & $3.69 \pm 0.31^{\mathrm{dG}}$ \\
\hline Carraway & $10.14 \pm 0.11^{\mathrm{cEF}}$ & $11.24 * \pm 0.48^{\mathrm{bGH}}$ & $12.04 \pm 0.54^{\mathrm{abEFG}}$ & $12.8 \pm 1.01^{\mathrm{aG}}$ & $8.85 \pm 0.33^{\mathrm{eFG}}$ & $9.3 \pm 0.28^{\mathrm{cdFG}}$ \\
\hline Cloves & $1056.14 \pm 23.39^{\mathrm{bA}}$ & $1310.91^{*} \pm 19.10^{\mathrm{aA}}$ & $843.63 \pm 39.40^{\mathrm{cA}}$ & $1084.65 \pm 21.17^{\mathrm{bA}}$ & $447.37 \pm 14.66^{\mathrm{eA}}$ & $527.12 \pm 23.83^{\mathrm{dA}}$ \\
\hline Garlic & $17.49 \pm 1.39^{\mathrm{bEF}}$ & $17.92 \pm 0.36^{\mathrm{bG}}$ & $7.71 \pm 0.50^{\mathrm{dFG}}$ & $8.29 \pm 0.35^{\mathrm{dG}}$ & $14.62 \pm 2.69^{\mathrm{cF}}$ & $22.89 \pm 1.25^{\mathrm{aF}}$ \\
\hline Nutmeg & $26.03 \pm 0.57^{\mathrm{cE}}$ & $19.89 * \pm 0.52^{\mathrm{dG}}$ & $30.88 \pm 1.48^{\mathrm{bE}}$ & $34.6 \pm 1.92^{\mathrm{aEF}}$ & $10.85 \pm 0.72^{\mathrm{eFG}}$ & $9.33 \pm 1.05^{\mathrm{eG}}$ \\
\hline Onion & $4.98 \pm 0.37^{\mathrm{abF}}$ & $5.3 \pm 0.49^{\mathrm{aH}}$ & $3.86 \pm 0.19^{\mathrm{cG}}$ & $4.42 \pm 0.30^{\mathrm{bcG}}$ & $4.39 \pm 0.69^{\mathrm{bcG}}$ & $4.3 \pm 0.08^{\mathrm{bcG}}$ \\
\hline Oregano & $141.46 \pm 2.40^{\mathrm{aD}}$ & $148.02 \pm 2.41^{\mathrm{aD}}$ & $67.43 \pm 5.76^{\mathrm{cD}}$ & $100.43 \pm 4.48^{\mathrm{bD}}$ & $24.18 \pm 1.68^{\mathrm{dE}}$ & $142.32 \pm 8.17^{\mathrm{aB}}$ \\
\hline Rosemary & $10.36 \pm 1.50^{\mathrm{dEF}}$ & $39.92 \pm 1.31^{\mathrm{bF}}$ & $9.9 \pm 1.15^{\mathrm{dFG}}$ & $31.13 \pm 4.99^{\mathrm{cFG}}$ & $13.66 \pm 0.20^{\mathrm{dF}}$ & $58.5 \pm 3.81^{\mathrm{aE}}$ \\
\hline Thyme & $202.29 \pm 14.80^{\mathrm{aB}}$ & $149.05 \pm 1.56^{\mathrm{bD}}$ & $88.89 \pm 6.85^{\mathrm{dC}}$ & $126.99 \pm 4.30^{\mathrm{cC}}$ & $141.81 \pm 5.43^{\mathrm{bB}}$ & $138.91 \pm 7.05^{\mathrm{bcB}}$ \\
\hline
\end{tabular}

a, b, c, d, e, f Means $(n=3)$ with the same superscripts within the same row do not differ significantly $(\mathrm{p}>0.05)$

A, B, C, D, E, F, G, HMeans $(n=3)$ with the same superscripts within the same column (for each method separately) do not differ significantly $(\mathrm{p}>0.05)$

$T E$ trolox equivalent

*Data shown previously in [21]

**Data shown previously in [20] 
extraction with $60 \%$ aqueous ethanol, reported much higher $\mathrm{ABTS}^{\bullet+}$ scavenging activity and FRAP values of both extracts in comparison to the data shown in this study which could result from the higher content of phenolic compounds noted for those extracts. The next group of extracts included spices and herbs with mid antioxidant activity i.e. oregano, thyme, basil and rosemary. Previously, it was shown that thyme and rosemary could show high radical scavenging activity $[6,8]$. Black seed, cardamom, caraway, garlic and onion were characterized by very low and nutmeg by low antioxidant activity determined by all three methods (ranging from 1.8 to $27.5 \mu \mathrm{mol}$ TE/g for DPPH, 7.32-93.5 $\mu \mathrm{mol}$ $\mathrm{TE} / \mathrm{g}$ for ABTS and 3.52-34.6 $\mu \mathrm{mol} \mathrm{TE} / \mathrm{g}$ for FRAP). The antioxidant activity of water and $70 \%$ methanol extracts of black seed was previously shown by Hameed et al. [34] who reported that after the extraction with aqueous alcohol the ABTS and FRAP values (equaled to, respectively $62.2 \mu \mathrm{mol}$ $\mathrm{TE} / \mathrm{g}$ DW and $5.42 \mathrm{mg} \mathrm{TE} / \mathrm{g} \mathrm{DW}$ ) were higher than in water extracts $(47.5 \mu \mathrm{mol} / \mathrm{g}$ DW and $3.17 \mathrm{mg} \mathrm{TE} / \mathrm{g} \mathrm{DW}$, respectively). In our study the $\mathrm{ABTS}^{\bullet+}$ scavenging activity of black seed extracted with ethanol was significantly lower than after extraction with water, and both ABTS values were lower than literature data [34]. Black seed (Nigella sativa) is mainly known as the source of oil. Few studies focused on the antioxidant activity of the seeds. Although the antioxidant activity of black seed is low, the effect of this spice addition to meat (chicken and pork) provided significant reduction of lipid and protein oxidation in comparison to other spices known as potent antioxidants [20,21]. This effect requires further investigation.

According to Gorinstein et al. [48] the $\mathrm{DPPH}^{\bullet}$ scavenging activity of garlic extract after short-time extraction with 50\% methanol equaled to $7.0 \mu \mathrm{mol} \mathrm{TE} / \mathrm{g} \mathrm{DW}$ which is similar to our results, although the ABTS $(23.7 \mu \mathrm{mol} \mathrm{TE} / \mathrm{g} \mathrm{DW})$ and FRAP $(6.9 \mu \mathrm{mol} \mathrm{TE} / \mathrm{g} \mathrm{DW})$ values of the extract were significantly lower than reported in our study. It could be only supposed that the differences between our data and literature data resulted from the various methodology steps of DPPH method applied by others. In that study [48] the antioxidant activity of onion extract quantified by the three assays was higher in comparison to our results.

Generally, the rank of extracts according the antioxidant activity was similar in all methods and it was as followed: clove $>>$ allspice $>$ bay leaf $>$ thyme $\approx$ oregano $>$ basil $>$ rosemary $>$ nutmeg $>$ garlic $\approx$ caraway $\approx$ black seed $\approx$ onion $\approx$ cardamom. Thus, the $r$ Pearson's coefficients for the correlation between the results of the three assays are very high, above 0.95 (Table 3). Similar order of some spice extracts provided by the ABTS assay was previously showed by Assefa et al. [9] who found the $80 \%$ aqueous methanol extract of clove to be the most potent antioxidant and cardamom extract to have the lowest antioxidant activity. $r$ Pearson's correlation coefficient calculated for the relation between the literature data [9] and the ABTS values of the spice and herb extracts obtained after $24 \mathrm{~h}$ extraction with $50 \%$ ethanol was 0.99. Mariutti et al. [52] found different ranking order of the spice and herb extracts (in ethanol) provided by the ABTS as well as DPPH radical scavenging activities with the rosemary extract being more potent antioxidant than allspice or bay leaf and garlic extract showing higher radical scavenging activity than basil. In that study [52] caraway and onion extracts were characterized by the lowest antioxidant activities, as it was observed in our study.

Considering that the phenolic antioxidants could be responsible for the antioxidant activity of plants, correlation coefficients were calculated between the TPC, TFC values and the radical scavenging activities and metal chelating properties. Table 3 represents correlation matrix. All $r$ Pearson's coefficients were statistically significant at $p=0.05$. The highest correlation was recorded between TPC and the antioxidant activity investigated by all three methods, namely FRAP $(r=0.98, p<0.05)$, ABTS $(r=0.98, p<0.05)$ and DPPH $(r=0.95, p<0.05)$. This suggested that phenolic compounds contributed significantly to the antioxidant activity of the extracts as it was well documented by others [31, 35, 36, 40, 44]. Weaker correlation was observed between TFC and the antioxidant activities which was noted previously by Assefa et al. [9]. This could be due to the fact that phenolics constitute a large group of compounds with various structures and antioxidant properties. Flavonoids are often bound to the sugar moieties forming glycosides which were reported to be weaker DPPH ${ }^{\bullet}$ scavengers on a weight basis than their aglycones or phenolic acids due to the inclusion of non-participating structures like sugars [53].

\section{Quantification of phenolic compounds}

Phenolic profiles of spices and herbs tested in this study were investigated using UPLC method for the samples extracted during $24 \mathrm{~h}$ with $50 \%$ aqueous ethanol since most of these samples showed the highest values of TPC as well as the highest antioxidant activity. Considerable variation could be found in the phenolic profiles of selected spices and herbs (Table 5). As can be seen, the major phenolic acids in tested extracts were caffeic acid (CA), $p$-coumaric acid (p-CumA) and p-hydroxybenzoic acid (p-HBA) with the highest levels found in caraway, basil and cloves (CA); rosemary; black seed and oregano (p-CumA) as well as in garlic, clove and bay leaf (p-HBA). All these phenolic acids were principle phenolic compounds reported in spice and herb extracts, together with chlorogenic acid (ChA) found in this work mainly in onion $(40.2 \mathrm{mg} / \mathrm{kg} \mathrm{DW})$ and protocatechuic acid (PCatA) detected in great amount in cloves $(79.6 \mathrm{mg} / \mathrm{kg} \mathrm{DW})$. The levels of phenolic acids reported by others varied in a broad range thus it is hard to compare the results with literature data. Vallverdú-Querald et al. [8, 30] 


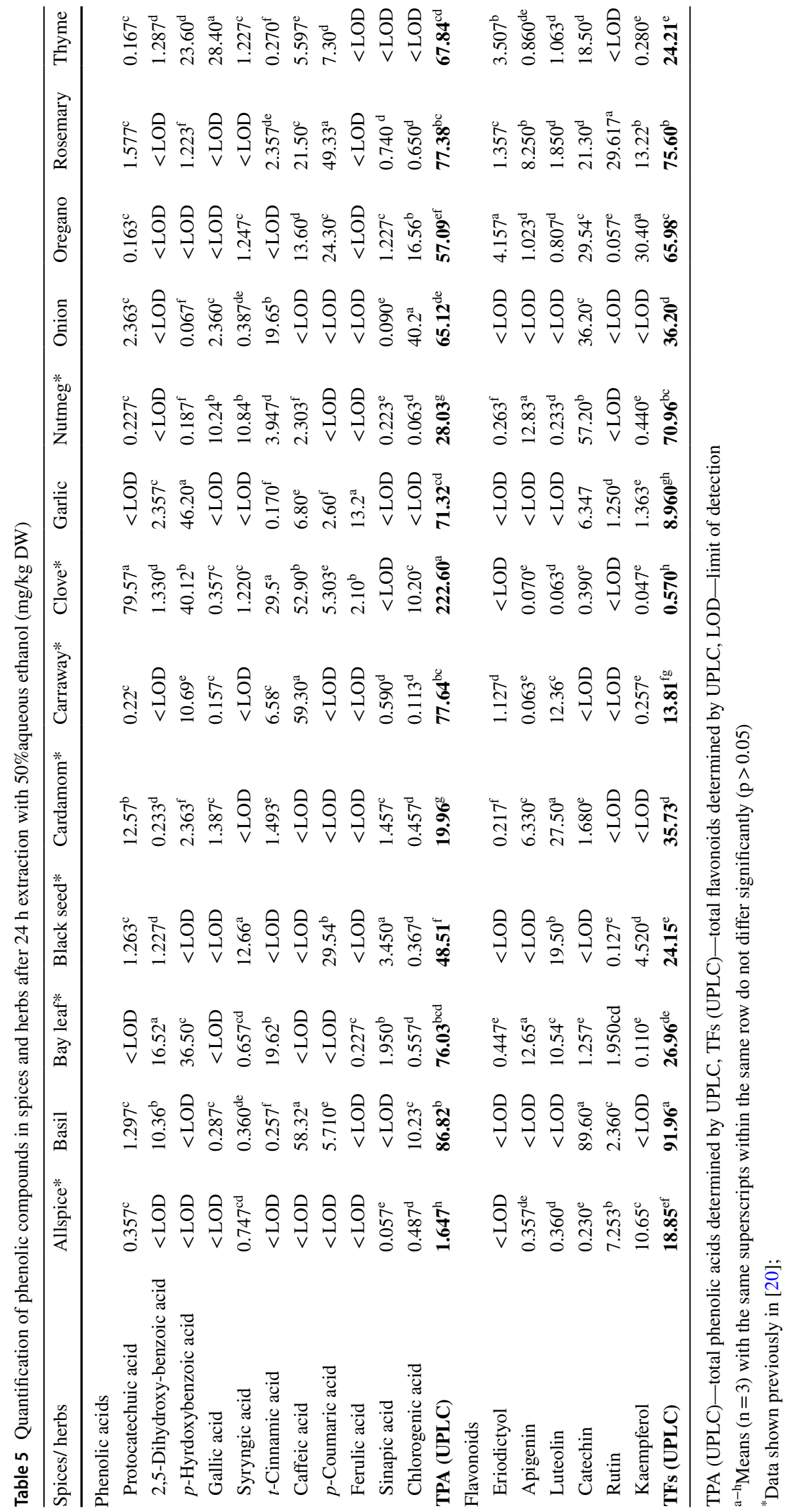


noted similar to our data content of CA in oregano, thyme and nutmeg after 20 min extraction in 50\% aqueous ethanol, equaled to 10.6, 6.6 and around $2 \mathrm{mg} / \mathrm{kg} \mathrm{DW}$, respectively, and lower content of CA in caraway and rosemary. CA was also found in garlic, but twice lower than in this work [33]. Shan et al. [35] showed much higher levels of the phenolic acids in basil, caraway, cardamom, clove, oregano, rosemary and thyme than reported in this study; e.g. the content of CA in thyme after extraction with $80 \%$ methanol for $24 \mathrm{~h}$ was 100 times higher $(548 \mathrm{mg} / \mathrm{kg} \mathrm{DW})$ than in our research. In addition, in aforementioned study the CA was not detected in clove, instead being found in bay leaf ( $304 \mathrm{mg} / \mathrm{kg} \mathrm{DW}$ ) and cardamom $(159 \mathrm{mg} / \mathrm{kg} \mathrm{DW})$ extracts. CA was also previously quantified in black seed at the level of $4.06 \mathrm{mg} / \mathrm{kg}$ DW [34] and onion [33] although it was not detected in these spices in our study. Opposite to our work $p$-CumA acid was not detected previously in clove and rosemary [35, 54], nor in oregano, thyme, [54] whereas it was observed by Shan et al. [35] in bay leaf and caraway. Vallverdú-Querald et al. $[8,30]$ reported lower level of p-CumA in oregano, rosemary and thyme when comparing to our results and in contrast to our study the authors $[8,30]$ detected this phenolic acid in bay leaf, caraway and nutmeg. Lower level of p-CumA was also found by Toma et al. [36] in black seed aqueous methanol (70\%) extract (4 mg/kg DW).

p-HBA was reported previously to be one of the most abundant phenolic acids in rosemary (15.16 mg/kg DW) [8] whereas in our research it was found in this herb at level of $1.22 \mathrm{mg} / \mathrm{kg}$ DW. Moreover, p-HBA was quantified by Vallverdú-Querald et al. [8] in bay leaf, caraway, nutmeg and thyme with levels ranging from 1.07 to $4.38 \mathrm{mg} / \mathrm{kg} \mathrm{DW}$ and in contrast to our work also in oregano $(2.5 \mathrm{mg} / \mathrm{kg} \mathrm{DW})$.

Shan et al. [35] detected PCatA in sweet basil $(415 \mathrm{mg} / \mathrm{kg}$ DW) and nutmeg (59.1 mg/kg DW) in higher levels than in our study, but not in bay leaf, cloves, rosemary, thyme and caraway [35, 38]. Although, this phenolic acid was quantified in bay leaf, nutmeg, onion, oregano, rosemary and thyme by others at the higher levels than in our study [8, 30, 33].

In this study, the highest content of gallic acid (GA) was observed in thyme $(28.4 \mathrm{mg} / \mathrm{g} \mathrm{DW})$ then nutmeg $(10.8 \mathrm{mg} / \mathrm{g}$ DW), onion, cardamom, clove, basil and caraway (Table 5). GA was not quantified in black seed, whereas it was observed previously by Mechraoui et al. [37] in 70\% aqueous ethanol extract of the spice at the level of $139 \mathrm{mg} / \mathrm{kg}$ DW. Shan et al. [35] detected GA in clove and thyme in much higher levels than in this study, but not in other abovementioned herbs and spices. In comparison to our results higher level of GA was reported in onion by Cheng et al. [55].

Based on the data from Table 5 it could be seen that the level of sinaptic acid (SA) varied in the range from 0.057 in allspice to $3.45 \mathrm{mg} / \mathrm{kg}$ DW in black seed. Syringic acid (SyA) was found in the highest quantity in black seed
$(12.7 \mathrm{mg} / \mathrm{kg} \mathrm{DW})$ and nutmeg $(10.8 \mathrm{mg} / \mathrm{kg} \mathrm{DW})$ whereas ferulic acid (FA) in garlic (13.2 mg/kg DW). Similar level of SyA was previously detected in bay leaf, oregano, thyme and in contrast to our results this phenolic acid was identified in caraway and rosemary $[8,30]$. Yang et al. [33] reported the higher level of SyA in 30\% aqueous ethanol extract of fresh onion than in our study. Opposite to our study FA was found in caraway, nutmeg, oregano, rosemary, thyme $[8,30]$, black seed [36] and onion [33] and the content of FA in bay leaf was 10 times higher [8] when comparing to our results.

In this study, among flavonoids the most abundant was catechin found mainly in basil $(89.6 \mathrm{mg} / \mathrm{kg} \mathrm{DW})$ and in nutmeg $(57.2 \mathrm{mg} / \mathrm{kg} \mathrm{DW})$. A high level of kaempferol was quantified in oregano $(30.4 \mathrm{mg} / \mathrm{kg} \mathrm{DW})$ whereas luteolin in cardamom (27.5) and black seed (19.5 mg/kg DW). Rutin was identified mainly in rosemary $(29.6 \mathrm{mg} / \mathrm{kg} \mathrm{DW})$. Catechin was previously detected in basil, nutmeg, rosemary [35], onion and garlic [33] in higher quantity than in this study. It was also found in caraway [30] although it was not reported in this work. In comparison to our results higher level of kaempferol was identified in caraway, clove, oregano [35], onion and garlic [33] but similar amounts were quantified in black seed [34, 36, 37]. Rutin was found previously in bay leaf at the level of $929.4 \mathrm{mg} / \mathrm{kg}$ DW and opposite to our results also in nutmeg at the level of $34.2 \mathrm{mg} / \mathrm{kg}$ DW [38].

\section{Chemometric analysis}

Chemometric approach was used for the samples obtained after $24 \mathrm{~h}$ extraction in 50\% ethanol, including data on the antioxidant activity, total phenolic content and content of individual compounds. To put more insight into the data and to understand the relationships between variables and samples, PCA was performed. PCA is unsupervised pattern recognition technique of multivariate analysis and gives the possibility to compress data from a higher to a lower dimensional space (few principal components) that can be later used to visualize data structure almost without any loss of information. This could be obtained without any preliminary assumptions about data distribution and enables to excluded redundancy [56]. Thus, PCA is a first step to other chemometric techniques like GDA.

Based on the PCA results, the first eight PCs (principal comonents) were extracted with eigenvalue greater than 1 and together they explained $89.5 \%$ of the total variance. The PC1 accounted for $33.8 \%$, PC2 for $13.1 \%$ of the variance in the dataset (Fig. 3). According to the loaded values, which express the correlations between PCs and variables, it could be stated that ABTS, FRAP, DPPH, TFC, TPC, PCatA, TPA, t-CA ( $t$-cinnamic acid), p-HBA determined sample distribution along PC1, whereas TFs, kaempferol, catechin and luteolin along PC2 (Fig. 3a). This was proven by high r Pearson's 


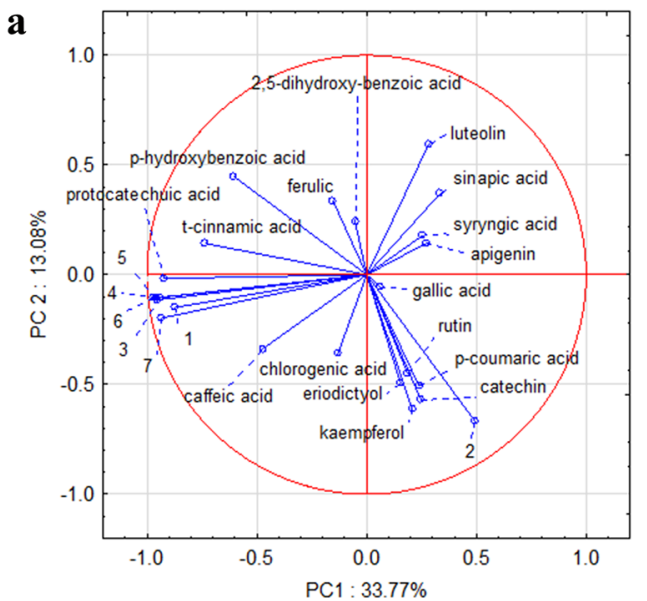

b

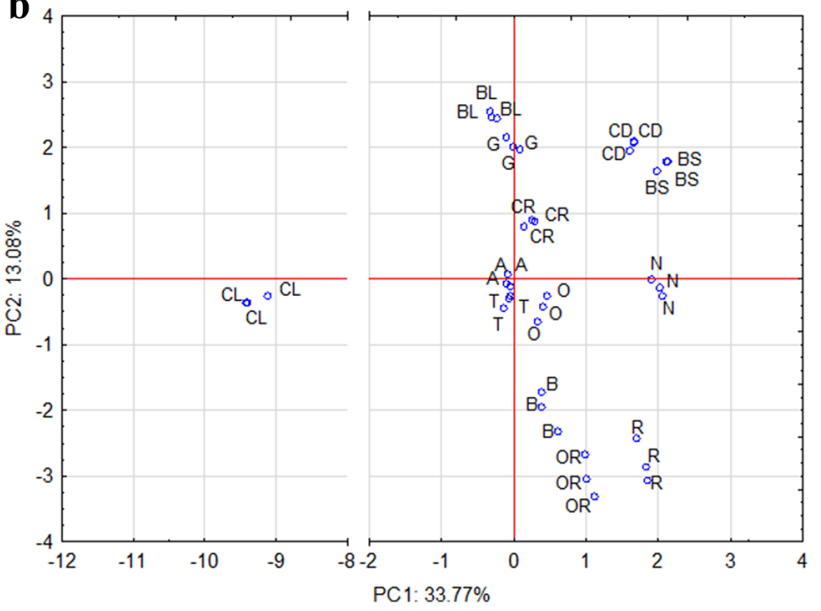

Fig. 3 Projections of the (a) variables onto the factor plane defined by principal components (PC1 and PC2). The numbers $1-7$ are related to the variables: 1-TPA (UPLC); 2-TFs (UPLC); 3-DPPH $\mu \mathrm{mol}$ $\mathrm{TE} / \mathrm{g}$; 4-FRAP $\mu \mathrm{mol} \mathrm{TE} / \mathrm{g} ; 5$-TEAC (ABTS) $\mu \mathrm{mol} \mathrm{TE} / \mathrm{g} ; 6$ mg GAE/g; 7-TFC mg QE/g; Projection of the (b) scores onto the factor plane: A-allspice, B-basil, BL-bay leaf, BS - black seed, $\mathrm{CD}$-cardamom, $\mathrm{CL}$-clove, $\mathrm{CR}$-caraway, $\mathrm{G}$-garlic, $\mathrm{N}$-nutmeg, $\mathrm{O}$-onion, OR—oregano, $\mathrm{R}$-rosemary, $\mathrm{T}$ - thyme

correlation coefficients between these variables and suggested that the antioxidant activity of the extracts was mainly attributed to the phenolic compounds. PCA analysis confirmed that clove extract showed high antioxidant activity and total phenolic content, including total flavonoids and total phenolic acids (Fig. 3b). Moreover rosemary extract was related to the high content of rutin and $\mathrm{p}$-CumA, but not $\mathrm{p}$-HBA as it was previously shown by others [8]. It could be clearly observed that black seed was related to the high content of SyA and SA but low antioxidant activity and TPC, TFC, TPA. Low antioxidant activity and TPC, TFC and TPA but high level of luteolin was observed in cardamom extract, whereas high catechin content in basil as well as in oregano, the latter was also characterized by the high content of kaempferol.
Results of PCA i.e. eight PCs (with eigenvalue above 1) were taken as variables for GDA. This enabled to lower the dimension of variables for GDA and eliminated the redundancy, since some parameters like these ones of the antioxidant activity and TPC values were highly correlated. GDA is supervised pattern recognition technique which enable to obtain discriminant functions maximizing the ratio of between-class variance and minimize the ratio of withinclass variance [57]. All discriminant functions were statistically significant. The first discriminant function accounted for $71.98 \%$ of total variance, and the second one for $9.85 \%$ (Table 6). The importance of the variables (PCs) in the canonical function was discussed based on standardized canonical discriminant function coefficients (Table 6). The higher the absolute value of standardized coefficient the higher the discrimination power of the related $\mathrm{PC}$ is. Thus, the PC1 related to. ABTS, FRAP, DPPH, TFC, TPC, PCatA, TPA, $t-C A, p-H B A$ contributed the most to the first canonical function (Root 1), whereas the PC2 and PC4 (related to TFs, kaempferol, luteolin and catechin as well as to 2,4-dihydroxybenzoic acid and eriodicyol, respectively) to the second one (Root 2). The third discriminant function (Root 3) was contributed by the PC7 related to SyA and PC8 related to CA. All samples were discriminated with $100 \%$ classification's propriety (Fig. 4) which proved excellent classification ability of the built discrimination model.

\section{Conclusions}

The results of this study indicated clearly that the content of phenolic compounds and the antioxidant activity depended strongly on the solvent and time of extraction. The solvent type played a key role in the phenolic extraction and the antioxidant activity of the extract. From the safety point of view the most suitable solvents for extraction are water or ethanol. To increase the yield of extraction process binary solvents are often used. Mixing water and ethanol provides the modification of polarity and thus influence the efficiency of extraction. Generally, 50\% aqueous ethanol was highly efficient to extract the phenolic compounds from tested herbs and spices. Thus, the antioxidant activity of the plan materials assessed by ABTS, DPPH and FRAP methods which was mainly related to the phenolic compounds was mostly the highest after extraction with 50\% ethanol comparing to both, water and ethanol extracts. However, it was hard to point the best solvent for only flavonoid extraction. Time of extraction could also affect the process. $24 \mathrm{~h}$ extraction gave higher values of TPC and the antioxidant activity than short time extraction, although the effect of time was not observed for TFC. Based on the results obtained the extracts used in this study could be divided into four groups with very high antioxidant activity (clove), high antioxidant activity (allspice 
Table 6 Standardized canonical discriminant function coefficients

\begin{tabular}{lllrlrrrl}
\hline & Root 1 & Root 2 & Root 3 & Root 4 & Root 5 & Root 6 & Root 7 & Root 8 \\
\hline PC1 & -1.355 & -0.035 & 0.077 & -0.002 & 0.021 & 0.000 & -0.015 & -0.008 \\
PC2 & -0.448 & 1.133 & -0.148 & -0.509 & 0.092 & -0.188 & 0.345 & -0.042 \\
PC3 & 0.612 & -0.651 & 0.592 & -0.362 & -0.017 & -0.605 & -0.010 & -0.138 \\
PC4 & -0.379 & -1.061 & -0.047 & -0.097 & -0.405 & 0.168 & 0.611 & 0.285 \\
PC5 & -0.401 & 0.158 & -0.286 & -0.223 & -0.936 & 0.007 & -0.163 & -0.209 \\
PC6 & 0.174 & 0.473 & 0.517 & -0.460 & -0.232 & 0.007 & -0.314 & 0.723 \\
PC7 & -0.221 & -0.558 & -0.669 & -0.587 & 0.261 & 0.061 & -0.144 & 0.019 \\
PC8 & -0.631 & 0.035 & -0.719 & 0.477 & -0.069 & -0.604 & -0.016 & 0.232 \\
Discrimination \% & 71.98 & 9.85 & 5.54 & 3.94 & 3.34 & 2.42 & 1.50 & 1.43 \\
Cumulative \% & 71.98 & 81.83 & 87.36 & 91.30 & 94.64 & 97.07 & 98.57 & 100.00 \\
\hline
\end{tabular}

From PCA the individual PCs were related to the parameters: PC1-ABTS, FRAP, DPPH, TFC (total flavonoid content), TPC (total polyphenol content), protocatechuic acid (PCatA), TPA (total phenolic acids), $t$-cinnamic acid (tCA), p-hydroxybenzoic acid (p-HBA); PC2 - TFs (total flavonoids from UPLC), kaempferol, luteolin and catechin; PC3 - p-coumaric acid ( $p$-CumA), sinapic acid (SA); PC4-2,4-dihydroxybenzoic acid, eriodicyol; PC5-rutin, ferulic acid (FA); PC6-gallic acid (GA), apigenin, chlorogenic acid (ChA); PC7—syringic acid (SyA); PC8—caffeic acid (CA)
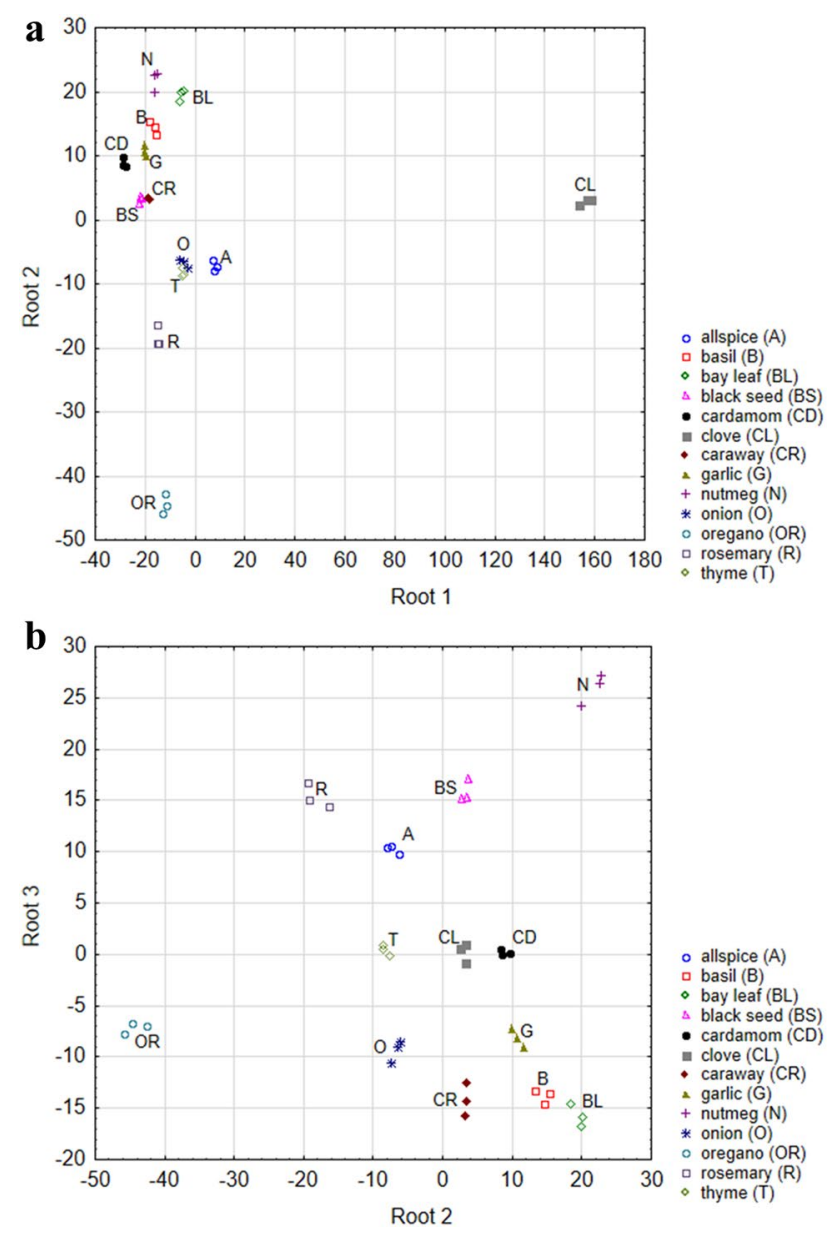

Fig. 4 GDA classification of extracts according to Root 1 versus Root 2 (a) and Root 2 versus Root 3 (b) and bay leaf), moderate antioxidant activity (basil, oregano, thyme and rosemary) and low antioxidant activity (nutmeg, black seed, cardamom, caraway, garlic and onion). This discrimination was proven by the chemometric analysis. Based on PCA, the contribution of phenolic compounds especially PCatA, t-CA, p-HBA, to the antioxidant activity of extracts was shown. Finally, according to the GDA the noticeable discrimination of samples was performed based on the PCs, showing a huge diversity of the plant materials according the phenolic profiles and the antioxidant properties.

Funding This research project was funded by the National Science Centre, Poland (Grant No. 2014/15/D/NZ9/04261).

\section{Declarations}

Conflict of interest The authors declare that they have no conflict of interest.

Research involving human and animal participants The manuscript does not contain experiments using animals or human studies.

Open Access This article is licensed under a Creative Commons Attribution 4.0 International License, which permits use, sharing, adaptation, distribution and reproduction in any medium or format, as long as you give appropriate credit to the original author(s) and the source, provide a link to the Creative Commons licence, and indicate if changes were made. The images or other third party material in this article are included in the article's Creative Commons licence, unless indicated otherwise in a credit line to the material. If material is not included in the article's Creative Commons licence and your intended use is not permitted by statutory regulation or exceeds the permitted use, you will need to obtain permission directly from the copyright holder. To view a copy of this licence, visit http://creativecommons.org/licenses/by/4.0/. 


\section{References}

1. M.H.H. Roby, M.A. Sarhan, K.A.H. Selim, K.I. Khalel, Ind. Crops Prod. 43, 827 (2013)

2. M.K. Khan, L. Paniwnyk, S. Hassan, Polyphenols as natural antioxidants: sources, extraction and applications in food, cosmetics and drugs, in Plant Based "Green Chemistry 2.0": Moving from Evolutionary to Revolutionary. ed. by Y. Li, F. Chemat (Springer, Singapore, 2019), pp. 197-235

3. I.B. Jaganath, A. Crozier, in Plant Phenolics and Human Health: Biochemistry, Nutrition, and Pharmacology. ed. by C.G. Fraga (Wiley, New York, 2009), pp. 1-49

4. S. Sepahpour, J. Selamat, M.Y.A. Manap, A. Khatib, A.F.A. Razis, Molecules 23, 1 (2018)

5. E. Dvorackova, M. Snoblova, L. Chromcova, P. Hrdlicka, Food Sci. Biotechnol. 24, 1201 (2015)

6. J.S. Nikolic, V.D. Mitic, V.P. Stankov Jovanovic, M.V. Dimitrijevic, G.S. Stojanovic, J. Food Meas. Charact. 13(3), 2167-2176 (2019)

7. M. Przygodzka, D. Zielińska, Z. Ciesarová, K. Kukurová, H. Zieliński, LWT_-Food Sci. Technol. 58, 321 (2014)

8. A. Vallverdú-Queralt, J. Regueiro, M. Martínez-Huélamo, J.F. Rinaldi Alvarenga, L.N. Leal, R.M. Lamuela-Raventos, Food Chem. 154, 299 (2014)

9. A.D. Assefa, Y.S. Keum, R.K. Saini, J. Food Meas. Charact. 12, 1548 (2018)

10. A.D. Gupta, V.K. Bansal, V. Babu, N. Maithil, J. Genet. Eng. Biotechnol. 11, 25 (2013)

11. C. Sánchez-Moreno, Ja. Larrauri, F. Saura-calixto, J. Sci. Food Agric. 270, 270 (1998)

12. N.J. Miller, C. Rice-Evans, M.J. Davies, V. Gopinathan, A. Milner, Clin. Sci. 84, 407 (1993)

13. M. Ozgen, R.N. Reese, A.Z. Tulio, J.C. Scheerens, A.R. Miller, J. Agric. Food Chem. 54, 1151 (2006)

14. K. Mishra, H. Ojha, N.K. Chaudhury, Food Chem. 130, 1036 (2012)

15. E.A. Shalaby, S.M.M. Shanab, Indian J. Mar. Sci. 42, 556 (2013)

16. I.F.F. Benzie, J.J. Strain, Methods Enzymol. 299, 15 (1999)

17. C. Sánchez-Moreno, J.A. Larrauri, F. Saura-Calixto, J. Sci. Food Agric. 76, 270 (1998)

18. M. Muzolf-Panek, A. Waśkiewicz, R. Kowalski, P. Konieczny, J. Food Process. Preserv. 40, 899 (2016)

19. R. Re, N. Pellegrini, A. Proteggente, A. Pannala, M. Yang, C. RiceEvans, Free Radic. Biol. Med. 26, 1231 (1999)

20. M. Muzolf-Panek, A. Kaczmarek, J. Tomaszewska-Gras, R. Cegielska-Radziejewska, T. Szablewski, M. Majcher, K. StuperSzablewska, Antioxidants 9, 903 (2020)

21. M. Muzolf-Panek, A. Kaczmarek, J. Tomaszewska-Gras, R. Cegielska-Radziejewska, M. Majcher, Int. J. Food Prop. 22, 111 (2019)

22. V.L. Singleton, J.A. Rossi, Am. J. Enol. Vitic. 16, 144 LP (1965)

23. M. Rezaei, A. Ghasemi Pirbalouti, J. Food Meas. Charact. 13, 2470 (2019)

24. B. Adaramola, A. Onigbinde, IOSR, J. Pharm. Biol. Sci. 11, 33 (2016)

25. M.A. Alcântara, I. de Lima Brito Polari, B.R.L. de Albuquerque Meireles, A.E.A. de Lima, J.C. da Silva Junior, É. de Andrade Vieira, N.A. dos Santos, A.M.T. de Magalhães Cordeiro, Food Chem. 275, 489 (2019)

26. J. Yang, X.Q. Ou, X. Zhang, Z.Y. Zhou, L.Y. Ma, J. Food Sci. 82, 605 (2017)

27. S.Y. Park, K.B. Chin, Int. J. Food Sci. Technol. 45, 1153 (2010)

28. I.S. Che Sulaiman, M. Basri, H.R. Fard Masoumi, W.J. Chee, S.E. Ashari, M. Ismail, Chem. Cent. J. 11, 54 (2017)

29. K.K. Chew, M.Z. Khoo, S.Y. Ng, Y.Y. Thoo, W.M. Wan Aida, C.W. Ho, Int. Food Res. J. 18, 1427 (2011)
30. A. Vallverdú-Queralt, J. Regueiro, J.F.R. Alvarenga, M. MartinezHuelamo, L.N. Leal, R.M. Lamuela-Raventos, Food Sci. Technol. 35, 189 (2015)

31. E.A.A. Elhussein, E. Kurtulbaş, M. Bilgin, A.S. Birteksöz Tan, M. Hacioğlu, S. Şahin, J. Food Meas. Charact. 12, 2289 (2018)

32. S.C.M. Burri, A. Ekholm, Å. Håkansson, E. Tornberg, K. Rumpunen, J. Funct. Foods 38, 119 (2017)

33. D. Yang, F.R. Dunshea, H.A.R. Suleria, J. Food Process. Preserv. 44, $1(2020)$

34. S. Hameed, A. Imran, M. un Nisa, M.S. Arshad, F. Saeed, M.U. Arshad, M. Asif Khan, Int. J. Food Prop. 22, 714 (2019)

35. B. Shan, Y.Z. Cai, M. Sun, H. Corke, J. Agric. Food Chem. 53, 7749 (2005)

36. C.C. Toma, N.K. Olah, L. Vlase, C. Mogoşan, A. Mocan, Molecules 20, 9560 (2015)

37. O. Mechraoui, S. Ladjel, M.S. Nedjimi, M.L. Belfar, Y. Moussaoui, Sci. Study Res. Chem. Chem. Eng. Biotechnol. Food Ind. 19, 411 (2018)

38. M. Lu, B. Yuan, M. Zeng, J. Chen, Food Res. Int. 44, 530 (2011)

39. C.M. Galanakis, V. Goulas, S. Tsakona, G.A. Manganaris, V. Gekas, Int. J. Food Prop. 16, 382 (2013)

40. A. Noubigh, M. Abderrabba, E. Provost, J. Iran. Chem. Soc. 6, 168 (2009)

41. E. Sergerdiene, K. Jonsson, H. Szymusiak, B. Tyrakowska, I.M.C.M. Rietjens, N. Cenas, FEBS Lett. 462, 392 (1999)

42. M. Eskandari, J. Rembiesa, L. Startaite, A. Holefors, A. Valanciute, F. Faridbod, M.R. Ganjali, J. Engblom, T. Ruzgas, Anal. Chim. Acta 1075, 91 (2019)

43. J. Rothwell, A. Day, M. Morgan, J. Agric. Food Chem. 53, 4355 (2005)

44. B. Yang, A. Kotani, K. Arai, F. Kusu, Chem. Pharm. Bull. 49, 747 (2001)

45. National Center for Biotechnology Information. PubChem Compound Summary for CID 3314, Eugenol. https://pubchem.ncbi.nlm. nih.gov/compound/Eugenol. Accessed 26 Feb 2021

46. S. Gorinstein, H. Leontowicz, M. Leontowicz, J. Namiesnik, K. Najman, J. Drzewiecki, M. Cvikrová, O. Martincová, E. Katrich, S. Trakhtenberg, J. Agric. Food Chem. 56, 4418 (2008)

47. V. Lagouri, M. Guldas, O. Gurbuz, Food Sci. Biotechnol. 20, 1487 (2011)

48. S. Gorinstein, Y.P.B. Heo, J. Namiesnik, H. Leontowicz, M. Leontowicz, K.H.J. Cho, S. Kang, Eur. Food Res. Technol. 228, 903 (2009)

49. Y. Feng, F.R. Dunshea, H.A.R. Suleria, J. Food Sci. Technol. 57, $4671(2020)$

50. C. Chang, M. Yang, H. Wen, J. Chern, J. Food Drug Anal. 10, 178 (2002)

51. A. Žugić, S. Dordević, I. Arsić, G. Marković, J. Živković, S. Jovanović, V. Tadić, Ind. Crops Prod. 52, 519 (2014)

52. L.R.B. Mariutti, G.P.M. de Barreto, N. Bragagnolo, A.Z. Mercadante, Braz. Arch. Biol. Technol. 51, 1225 (2008)

53. Y. Lu, L.Y. Foo, Food Chem. 75, 197 (2001)

54. A. Wojdyło, J. Oszmiański, R. Czemerys, Food Chem. 105, 940 (2007)

55. A. Cheng, X. Chen, Q. Jin, W. Wang, J. Shi, Czech J. Food Sci. 31, $501(2013)$

56. I. Stanimirova, M. Daszykowski, B. Walczak, Talanta 72, 172 (2007)

57. L.A. Berrueta, R.M. Alonso-Salces, K. Héberger, Supervised pattern recognition in food analysis. J Chromatogr 1158, 196-214 (2007)

Publisher's Note Springer Nature remains neutral with regard to jurisdictional claims in published maps and institutional affiliations. 